\title{
Okul öncesi öğretmen adaylarının televizyon ve internette izlediği reklamlardaki çocuk haklarına ilişkin görüşleri*
}

\author{
Preservice preschool teachers' views on children's rights in \\ advertisements watched on television and the internet
}

\author{
Şenay Bulut Pedük ${ }^{1}$, Emine Ahmetoğlu², Ezgi Akşin Yavuz ${ }^{3}$
}

\begin{abstract}
Makale Geçmişi
Gelis : 13 Ekim 2020

Düzeltme : 16 May1s 2021

Kabul : 25 Ağustos 2021
\end{abstract}

Makale Türü

Araștirma Makalesi
Article History

Received : 13 October 2020

Revised : 16 May 2021

Accepted : 25 August 2021

Article Type

Research Article
Öz: Reklamlarda şarkı, müzik, dans gibi çocuğun ilgisini çeken unsurların ve sembollerin yer alması çocuğun reklamlarda gördüğü görüntülerden etkilenmesine neden olmaktadır. Reklamların çocuk haklarına uygun öğeler içermesi önemlidir. Erken çocukluk dönemi çocuklarla çalışacak öğretmen adaylarının çocuk haklarını gözetmesi ve çocuğun yararı ilkesine yönelik hareket etmesi, farkındalık sahibi olması gerekmektedir. Araştırmada, okul öncesi eğitimi alan öğretmen adaylarının ekranda (televizyon ve internet) izledikleri reklamların çocuk haklarına yer vermesine ilişkin görüşlerinin belirlenmesi amaçlanmıştır. Karma yönteme uygun olarak planlanan araştırmada hem nicel değerlendirme hem de nitel değerlendirme gerçekleştirilmiştir. Araştırmaya katılmayı gönüllü olarak kabul eden 45 okul öncesi öğretmen adayı çalışma grubunu oluşturmuştur. Bulgular frekans analizinin yanı sıra içerik analizi gerçekleştirilerek incelenmiştir. Araştırma sonuçlarına göre öğretmen adaylarının çoğu çocuk haklarını bilmektedir. En çok yaşama hakkı kategorisinde yer alan haklara örnekler vermekte ve çok azı reklamların çocuk haklarını koruduğunu düşünmektedir.

Anahtar Kelimeler: Okul Öncesi Öğretmen Adayı, Televizyon, İnternet, Reklam, Çocuk Hakları

Abstract: The presence of elements and symbols that attract the attention of the child, such as songs, music and dance, in advertisements causes the child to be affected by the images s/he sees in the advertisements. Preservice teachers who will work with preschool children should uphold children's rights, act towards the principle of the benefit of the child, and have awareness. -In the study, it was aimed to determine the opinions of pre-school teacher candidates about the advertisements they watch on the screen (television and internet) include children's rights. The research planned in accordance with the mixed method so both quantitative and qualitative assessment were carried out. The study group consisted of 45 pre-school preservice teachers who voluntarily agreed to participate in the research. The findings were analyzed by frequency and content analysis. Accordingly, most of the preservice teachers know children's rights. They give examples of right to live the most and few thinks that advertisements protect children's rights.

Keywords: Preschool Preservice Teacher, Television, Internet, Advertisement, Children's Rights

\footnotetext{
* Bu araştırma 6. Uluslararası Okul Öncesi Eğitimi Kongresi’nde (2019) sözlü bildiri olarak sunulmuştur. Başlıca Yazar:

${ }^{1}$ Trakya Üniversitesi, Eğitim Fakültesi, Temel Eğitim Bölümü, senaybulutpeduk@trakya.edu.tr, ORCID:0000-0001-6727-3298

2 Trakya Üniversitesi, Eğitim Fakültesi, Temel Eğitim Bölümü, emineahmetoglux@trakya.edu.tr, ORCID:0000-0001-7974-7921

${ }^{3}$ Trakya Üniversitesi, Eğitim Fakültesi, Temel Eğitim Bölümü, ezgiaksin@trakya.edu.tr, ORCID:0000-0002-9158-7550
} 


\section{SUMMARY}

\section{Introduction}

Social media tools such as television and the internet are increasingly used in our social lives thanks to technological advances, the development of television and media activities. Advertisements, an integral part of these tools, are seen as a means of reaching and appealing to masses through them. On TV and the internet, we frequently see advertisements that stimulate us but we do not have the chance of choice. Be it a child or an adult, the audience is affected by advertisements. Preschool children are more influenced by images because they think through symbols. Advertisements also affect children through songs, dance and music. Therefore, it is very important that they include items appropriate to children's rights.

Preschool preservice teachers, who will be working with young children, should be aware of children's rights and act on the principles of benefits to children and protecting them. Teachers' awareness of children's rights and their sense of protectiveness may influence both their own behaviours and the behaviours of their pupils' families. In particular, parents may need effective guidance to gain awareness about children's rights so that they can assess the appropriateness of the messages their children receive from advertisements.

\section{Method}

The study, designed using mixed research methods, aimed to assess the present situation and examine the views of preservice teachers by using a structured interview method. The study group of the research consists of preservice teachers who studied in the spring term of the 2018-2019 academic year in the Department of Preschool Education, Faculty of Education at Trakya University. The study group includes 45 preservice teachers, 38 females and 7 males, who voluntarily agreed to participate in the study.

The interview questions were prepared by reviewing the relevant literature. Personal information forms were used as data collection tools to obtain demographic information. The interview form that included 14 questions was presented to three field experts for analysis. After obtaining their views, the pilot application of the scale was finalized and tested on three preservice teachers, which concluded that the scale was comprehensible. Quantitative findings obtained from the research were expressed as numerical values with frequency and percentage analysis. In addition, the qualitative questions in the research were examined by performing content analysis. In the analysis of qualitative data, the percentage of agreement between coders were calculated to ensure the validity of the codings, thus the concord percentage was found as $93.71 \%$.

\section{Results}

Most of the preservice teachers stated that they were partially aware of children's rights, and the majority did not attend any courses or seminars on children's rights. Preservice teachers mostly gave examples about 
living rights, followed by development rights and protection rights. The fewest number of responses were about participation rights.

To determine the advertisements believed to observe children's rights and to estimate what children's right is included in these ads, firstly the participants were asked about the protection of children's rights. Almost half thought that the rights were partially protected, and very few thought children's rights were protected.

Advertisements in which the preservice teachers thought that the rights of children were considered were further examined in the categories of those published by companies, public services and non-governmental organizations. Accordingly, mostly companies stated their opinions about the protection of children's rights in the ads related to Children's Day on April 23rd, the environment, sustainability, education, nutrition and personal care.

Preservice teachers were asked about their favourite advertisement and how much of children's rights was protected in it. The most popular advertisements were in the food and beverage category. Most stated that children's rights were partially protected in their favourite advertisements.

\section{Conclusion and Discussion}

Preservice teachers spend three hours daily in front of screen, which is considered a proof that they encounter advertisements. Their response that they know or partially know about children's rights is a significant finding because having studied and learnt about the Convention of the Rights of Children will positively influence the behaviour of preservice teachers towards children's rights, which was also stated in research conducted by Leblebici and Çeliköz (2017), Covell and Howe (1995), Karaman and Kepenekçi (2006), and Değirmenci (2016). Preservice teachers' having partial knowledge on the topic can be compared to Koran (2012) and Tozduman Yaralı and Güngör Aytar (2017)'s finding that preschool teachers did not have adequate knowledge about children's participation rights. Banko (2017) and Harekett (2019) stated that practices on children's rights are not at a desirable level and that their perceptions and awareness should be improved. Thus, it can be concluded that education on the rights of children should be materialised and preservice teachers should be equipped with adequate knowledge and skills.

One third of the preservice teachers have attended lessons or seminars on the rights of children. In contrast to the idea that seminars and lessons positively affect attitudes towards children's rights, Yaşar Ekici (2014) with Platin and Ahmetoğlu (2020) did not identify any influence in their study.

The study indicated that the preservice teachers knew most about the rights to life and development, followed by the right to protection, and they knew least about the right to participation. Their ideas about the rights that can be protected in the advertisements are parallel with this result. Kop and Tuncel (2010), Kaya (2011), and Özkan (2013) emphasized that the rights to life and development as the rights that are 
known, and Kardeş Banko, Eren and Antakyalığglu (2017), Sop ve Topçu Bilir (2021) stated that preservice teachers did not have sufficient knowledge particularly about the participation rights. In this study, the preservice teachers did not include the participation rights when they assessed the contents, which can mean that a theoretically known right is not transferred to application or that there is not yet an awareness on the subject.

The participants thought that children's rights were observed in food advertisements. With respect to the recognition and learning of children's rights, this finding suggests that food elements should be inserted in advertisements, which is in line with the study results of Akay, Atalay Oral, Akpınar and Gül (2016).

Most of the preservice teachers stated that the advertisements they saw on the screen did not consider children's rights or they were considered partially. This indicates the necessity and meaningfulness of this study. Boztepe (2018) established that advertisements are influential on social functions. Within the framework of social development, advertisements that observe children's rights are needed. 


\section{GİRIŞ}

Çocuk ailesine doğar ve kendine has özellikleriyle birlikte, ailesi, akrabaları, komşuları, mahallesi ve giderek genişleyen çevresi tarafindan büyütülür. Büyüme sırasında gösterdiği gelişim de her anlamda çevresinden etkilenir. Senemoğlu (2018) bu durumu okul öncesi çocukların gelişimini kalıtım, hormonlar, kişilik özellikleri ve çevrenin etkilemesi olarak özetlemektedir. Çocuğun yaşadığı çevre içinde büyük rolü olan aile ve çocuğun fizyolojik ihtiyaçlarının karşılanması dışında, çocukların doğum sırası, arkadaş grupları, eğitimi ve kitle iletişim araçları gelişimini etkiler (Senemoğlu, 2018). Çocukların izledikleri filmler, televizyon programlarının içeriği, televizyonda yayınlanan reklamlar, müzik ve videolar, bilgisayar ve günümüz dijital araçlarında izlenen görüntüler bu araçlar arasında sıralanabilir. Medya araçlarından televizyon, çoğu aile için halen sosyalleşmenin ve haber almanın en önemli aracı olarak görülmektedir. Televizyon reklamlarından çocukların etkilenip etkilenmemeleri üzerine yapılan araştırmalar özellikle yaşın önemli olduğunu ortaya çıkarmıştır. Televizyon reklamları özellikle küçük çocuklar üzerinde daha etkili olmaktadır. Reklamlardan etkilenme çocuğun dünyasında reklamdaki ürünün yerine, ailenin çocuğun isteklerine gösterdiği hoşgörüsüne göre de değişmektedir (Önder ve Balaban Dağal, 2007)

Çağımızın en önemli iletişim aracı olan internetin kısa bir zaman dilimi içerisinde radyo, televizyon ve gazetenin gerçekleştiremediğini yaparak küresel ölçekte hızlı bir şekilde yaygınlaşması ile artık tek bir iletişim sisteminden bahsetmek mümkün değildir. İletişim teknolojilerinde yaşanan bu gelişmeler akıllı telefonların kapasitelerini ve dolayısıyla kullanım alanlarının sınırını da geliştirmektedir. Başlangıçta iletişim kolaylı̆̆ı, mobil olma, iletişimi her an mümkün kılabilme gibi özellikleri ile ön plana çıkan cep telefonları, günümüzde birçok farklı özelliği barındıran akıllı telefonlara evrilmiştir. Herhangi bir yaştan biri akıllı telefon kullanıcısı olabilirse de akıllı telefon kullanımına en çok uyum sağlayanlar Y, Z ve Alfa kuşağı bireylerdir. Y kuşağı için yaşam biçimi ve iletişim "hızlı", "kısa" ve "pratik" olarak ele alınmaktadır. E - iletişim bireyler arasındaki iletişimin temel biçimi durumuna gelmiştir (Anonim 2019). İnternet, her yaştan ve cinsiyetten insana farklı amaçlarla hizmet etmektedir. Internet reklamları ise 1994 yllından beri kullanılmaktadır (Yaman, 2009). Bugün her bireyin bir akıllı telefona sahip olması ve çocukların erişim kolaylığı özellikle anne baba ve okul öncesi öğretmenlerini reklamların çocuklar üzerinde etkileri ve çocukların hakları bağlamında bilgili olmaları gerektiğine dikkati çekmektedir. Ayrıca yazılı ve yazılı olmayan, büyük çeşitlilik gösteren formatlardaki (televizyon, video, sinema, reklâmlar, internet v.s.) mesajlara ulaşma, bunları çözümleme, değerlendirme ve iletme yeteneği kazanabilmek olarak tanımlanan medya okuryazarllğına sahip olmanın önemine dikkat çekilmektedir ( Solmaz ve Yılmaz, 2012). 
Reklamlar televizyon, radyo, gazete gibi kitle iletişim araçları ile mal ve hizmetlerin geniş halk kitlelerine tanıtımıdır. Günümüzde reklamlar medya aracılığ1 ile insanların sosyal hayatında daha çok yer almaktadır. Çocuklar küçük yaşlardan itibaren televizyonla ilgilenirler. Gündelik gözlemlerde de küçük çocukların reklamları izledikleri ve etkilendikleri görülmektedir. Televizyon karşısında zaman harcayan çocuk reklam spotuyla karşılaşmaktadır. Yapılan bir araştırmada çocukların maruz kaldığı reklam spotu sayısının 11500 olduğu belirtilmiştir (Anonim 2019; Önder ve Balaban Dağal, 2007; Tokgöz, 1982). Reklam spotu sayısı çocukların etkilenme düzeylerini belirlemede ölçüt olamaz. Ancak çocukların reklamları nasıl algıladıklarını anlamaya çalışmak gerektiğini, reklamların çocuk yararı ve hakları açısından incelenmesi gerektiğini göstermektedir. Doğrudan çocukları hedefleyen çocukların ürünü almaları ve kullanmaları yönünde mesaj içeren reklamların yanı sıra hedef kitlesi dolaylı olarak çocukların olduğu reklamların oranının \%78.4 olduğu belirlenmiştir (Özen, 1995). Bu durum çocukların ya da diğer kişilerin televizyon açıldığı anda hangi program izlenirse izlensin reklamlarla karşılaşma olasıllı̆ını yüksekliğini göstermektedir. Çocuklar reklamlara daha çok eğlenme isteği ile yaklaşmaktadırlar (Kapferer, 1991). Ayrıca reklamların biçimsel özellikleri ses, (müzik, konuşma, efekt), hareket ve görüntüleri çocukları reklam izlemeye sevk etmektedir. (Önder ve Balaban Dağal, 2007). Televizyon ve internet kullanımıyla çocuk haklarının yeniden yapılandırıldığı önemli bir alan olan dijital reklamcıllğın çocukların düşünce özgürlüğü, gelişme hakları, mahremiyet, ekonomik sömürüye karşı koruma dahil olmak üzere, çocuk hakları açısından belirli konuları gündeme getirmiştir (Verdoodt, 2019).

Çocuk hakları, çocuğun bedensel, zihinsel, duygusal, sosyal ve ahlaki bakımlardan saygınlıkla, sağlıklı bir biçimde gelişebilmesi için hukuk kuralları ile korunan yararlardır. Çocuk hakları, insan haklarının ayrılmaz bir parçasıdır. Çocuk hakları, günümüze ve geleceğe ait medeni bireyler yetiştirebilmek için dünyada çocuk haklarının korunması, savunulması ve geliştirilmesine ilişkin atılacak adımların oluşturulmasında rehber niteliğindedir. Bu kapsamda çocuk haklarının, eğitimin en temel unsuru olan okul öncesi eğitim ile çocuklara kazandırılması gerçeği ortaya çıkmaktadır (Sadıkoğlu ve Topsakal, 2017). Çocuklar başta olmak üzere toplumun diğer kesimleri ve araştırma kapsamında ögrretmen adayları da televizyon ve internet kullanımı ile medya okuryazarllğı konusunda ne kadar bilgiye sahip olurlarsa çocukların haklarını ne kadar iyi bilir ve içselleştirirlerse kendilerini ve çevrelerini medyanın zararlı etkilerinden koruyabilirler (Solmaz ve Yılmaz 2012).

Çocukların yaşamında önemli bir yeri olan okul öncesi öğretmenlerinin çocuk haklarının farkında olmaları, uygulamaları ve çocukları-aileleri bu anlamda bilinçlendirmeleri onların sorumluluğundadır. Araştırmalar erken dönemde çocuğun gelişiminde, benlik ve kişiliğin sağlam temeller üzerine kurulmasında ve çocuğun haklarını yaşayarak öğrenmesinde ailenin sunduğu 
fırsatlar yanı sıra okul öncesi öğretmenler son derece önemli kişiler olduğuna işaret etmektedir. Çocukların haklarını kullanabilmeleri, koruyabilmeleri ve haklarını arayabilmeleri için öncelikle haklarından haberdar olmaları gerekir. Çocuk Hakları Sözleşmesi’nin 42. maddesi de çocukların kendi haklarını öğrenmelerine yöneliktir. Okullar, çocukların insan hakları ve demokrasi kültürünü öğrendiği ve uygulandığ1 kurumlardır. Bu nedenle ilk eğitim kurumu olan okul öncesi eğitim kurumlarında çocuğun karşılaşacağı okul öncesi öğretmenler önemli tutum ve davranışlara sahiptir (Akman ve Ertürk, 2011; Özdemir Uluç, 2008). Öğretmenlik mesleğinin şekillenmeye başladığ1 öğrencilik döneminde okul öncesi öğretmen adaylarının da çocuk hakları konusundaki görüşleri oldukça değerlidir.

Yurt dışında yapılan çalışmalarda ebeveynlerin, okul öncesi öğretmenlerin ve öğretmen adaylarının çocuk haklarına ilişkin görüşleri, farkındalığı, bilgi ve uygulama düzeyleri, çocukların çocuk koruma uygulamalarına katılımı, öğretmenlerin ve ebeveynlerin çocuk katılımını teşvik etmeleri, iletişim ve akademik becerilerini desteklemedeki rollerine ilişkin çalışmalar yer almaktadır (Correia, Carvalho, Durães and Aguiar, 2020; Cudjoe, Abdullah and Manful, 2021; Gunathilaka, 2018; Faiz ve Kamer, 2017; Lawal and Ajayi, 2020; Olsson, 2020; Öztürk, 2019). Reklamlarda çocuk hakları boyutunda ise internet kullanımıyla çocuk haklarının yeniden yapılandırıldığı önemli bir alan olan dijital reklamcıllğın çocukların düşünce özgürlüğü, gelişme hakları, mahremiyet, ekonomik sömürüye karşı koruma dahil olmak üzere hakların farklı boyutlarını nasıl etkilediği ve reklamlarda haklarının nasıl kullanıldığı ele alınmış, çocuklara dijital gıda pazarlamanın, çocuk hedefli fast food TV reklamlarına maruz kalmanın fast food alımına etkisi çocuk hakları açısından incelenmiştir (Emond, Longacre, Drake, Titus, Hendricks, MacKenzie, Harris, Carroll, Cleveland, Gaynor and Dalton, 2019; Tatlow-Golden and Garde, 2020; Verdoodt, 2019).

Türkiye'de anne babaların; çocuk haklarını uygulama düzeyleri, ebeveyn tutumları, çocukların katılım hakkına yönelik görüşleri (Akyol, 2020; Ergün ve İpek, 2020; Kesayak ve Karatekin, 2020), okul öncesi öğretmenlerin; çocuk haklarına ilişkin tutum, davranış ve görüşleri, çocuk katılım hakkına ilişkin görüşleri (Aydınlık, 2017; Banko, 2017; Kor 2013; Kozikoğlu, 2017; Washington, 2010), okul öncesi dönemindeki çocukların gözünden çocuk hakları, çocuk kitaplarında çocuk hakları (Kent Kükürtçü 2019; Uysal Bayrak, Gök, Yörük ve Kaya, 2020; Yıldız, 2017), okul öncesi öğretmen adaylarının; çocuk haklarına ilişkin tutumları, algıları, görüşleri, çocuk katılım hakkı farkındalıklarını (Bilir Seyhan ve Arslan Cansever, 2017, Hareket, 2019; Pilatin ve Ahmetoğlu, 2020; Koran ve Avc1, 2017; Sop ve Topcu Bilir, 2021) incelemeye yönelik bazı çalışmalara rastlanmaktadır. Sadıkoğlu ve Topsakal (2017) çalışmalarında; çocuk hakları ile ilgili yapılan bilimsel çalışmaların daha çok betimsel nitelikte gerçekleştirildiği, görüş ve alg1, tutum çalışmaları ile hak 
ihlalleri konu alanlarına ağılık verilirken, çocuk hakları eğitimi konu alanına az yer verildiği ve eğitimin ilk basamağı olan okul öncesi eğitimde çok az sayıda çalışma yapıldığını ifade etmişlerdir. Okul öncesi öğretmen adayları üzerinde yürütülen çalısmalar olmasına karşın öğretmenlerin farkındalık durumlarını reklamlar gibi hızlı değişim gösteren bir araç üzerindeki görüşleri ile değerlendiren bir çalışmaya rastlanmamıştır. Kent Kükürtçü (2011) çalışmasında, öğretmenlerin çocuk hakları konusundaki bilgi kaynakları ile öğrenim düzeyleri arasındaki ilişkinin anlamlı olduğunu belirtmiştir. Öğretmenlerin çocuk hakları konusundaki bilgi kaynaklarının eğitim düzeyi arttıkça okul dışı kaynaklara yöneldiği özellikle lisans eğitimi alan öğretmenlerin okuldaki öğrenmelerinden çok internet kaynaklarına faydalandıklarını ifade etmeleri ise lisans eğitimi sırasında alınan eğitim ve farkındalıkların öğretmen adayları öğretmen olduklarında daha etkili olacağını düşündürmektedir.

Çocuğa dair yaşantısı olan başta aile olmak üzere okul öncesi çocuklarla iletişimi olan herkesin çocuk hakları ile ilgili farkındalıklarının artması çocuk haklarının etkili şekilde gelişmesini sağlayacaktır (Sadıkoğlu ve Topsakal, 2017). Çocuk hakları eğitimlerini uygulayacak olan; geleceğin öğretmenleri öğretmen adaylarının çocuk haklan ile ilgili tam anlamda bir bilgiye sahip olmaları, çocuk hakları konusunda bilgi edinerek eğitim ortamlarında kendileri tarafindan hak ihlali içeren davranışlar ile ilgili farkındalık geliştirmeleri (Koran, 2012) eğitim sürecini yürütürken çocuk hakları eğitimini nitelikli olarak gerçekleştirmelerini sağlayacaktır. Öğretmen adaylarının çocuk haklarının reklamlarda ne denli korunduğuna dair görüşlerinin belirlenmesi onların konu hakkındaki fikirlerini ve farkındalıklarını değerlendirmelerini sağlayacaktır. Çocuk haklarını içselleştirerek davranışa dönüştürme olasılıklarının artacağına inanılmaktadır. Öğretmen olacak adayların öğretmenliklerinde ebeveynlere çocuk hakları konusunda rehber olacağı ve toplumun bir üyesi olarak çocuk hakları ihlallerinin takipçisi olmalarını sağlayacağından çalısmanın önemli olduğu söylenebilir. Bu düşüncelerden hareketle araştırmada, okul öncesi eğitimi anabilim dalı öğretmen adaylarının ekranda (televizyon ve internet) izlediği reklamlardaki çocuk haklarına ilişkin görüşlerinin belirlenmesi amaçlanmıştır. Okul öncesi öğretmen adaylarının çocuk hakları konusunda kavramları içselleştiren ve bilen kişiler olarak göreve başlamalarının çocukların gelişimini desteklemede önemli olduğu düşünülmektedir.

\section{YÖNTEM}

Karma yöntem araştırmaları temel desenlerinden olan birleştirme deseni kullanılarak gerçekleştirilen araştırmada hem nicel hem de nitel veriler derlenerek veri sonuçları birlikte yorumlanmıştır. Nicel sonuçların genellikle eğilimleri, ilişkileri açıkladığı; nitel sonuçların ise 
bireylerin görüşlerini derinlemesine inceleme firsatı verdiği bu desende birlikte ele alınan sonuçlar daha fazla verinin bütüncül bir anlayışla ele alınmasını sağlar (Christensen, Johnson ve Turner, 2015; Creswell, 2017; Creswell ve Plano-Clark, 2015). Mevcut araştırmada da öğretmen adaylarının ekranda izledikleri reklamları çocuk hakları bakımından değerlendirmesi istenirken; öncelikle çocuk haklarına ilişkin bilgilerinin belirlenmesi maksadıyla nicel değerlendirmeyi hedefleyen sorular ardından çocuk haklarına dair bilgilerinin daha derinlemesine incelenebilmesi amacıyla nitel bir soru eklenmiştir. Reklamların çocuk haklarına yer vermesi durumuna ilişkin değerlendirmeler yapılırken de öğretmen adaylarının reklamlarda çocuk haklarının gözetilip gözetilmediğine dair görüşleri nicel olarak incelenirken; reklamlarda ele alınan, alınmayan ve alınabilecek olan çocuk haklarına dair görüşleri nitel yöntemle daha derinlemesine incelenmiştir. Nicel ve nitel verinin aynı anda ayrı sorularla toplanmasının ardından analiz gerçekleştirilmiştir. Elde edilen bulgular ise sonuç ve tartışma bölümünde nicel verinin öncelikle sunularak ardından burada elde edilen bulguların detaylı bilgi sağlayan nitel veri sonuçlarıyla desteklenmesi yoluyla tartışılmıştır.

\section{Çalışma Grubu}

Araştırmanın çalışma grubunu Trakya Üniversitesi Eğitim Fakültesi Okul Öncesi Eğitimi Anabilim Dalında 2018-2019 eğitim öğretim yılı bahar döneminde öğrenime devam eden öğretmen adayları oluşturmaktadır. İlgili dönemde eğitim öğretime devam eden tüm öğretmen adaylarına ulaşılarak araştırma hakkında bilgi verilmiştir. Çalışma grubu araştırmaya katılmayı gönüllü olarak kabul eden öğretmen adaylarından oluşmaktadır. Buna göre çalışma grubunda 38 kadın, 7 erkek toplam 45 öğretmen adayı mevcuttur. Öğretmen adaylarının yaş ortalaması 22,35’tir. Öğretmen adaylarına dair betimleyici bilgiler Tablo 1'de sunulmaktadır.

Tablo 1. Araştırmaya katılan öğretmen adaylarının cinsiyet, mezun olunan lise türü, anne ve baba öğrenim durumu, kardeş sayısı değişkenlerine göre frekans ve yüzde dağılımları

\begin{tabular}{llcc}
\hline Demografik Bilgiler & & $\boldsymbol{n}$ & $\boldsymbol{\%}$ \\
\hline \multirow{2}{*}{ Cinsiyet } & Kadın & 38 & 84.4 \\
& Erkek & 7 & 15.6 \\
\hline & Düz lise & 6 & 13.3 \\
Mezun Olunan Lise Türü & Meslek lisesi & 40.0 \\
& Anadolu lisesi & 18 & 40.0 \\
& Anadolu öğretmen lisesi & 18 & 4.2 \\
& Diğer & 2 & 60.0 \\
Anne Öğrenim Durumu & İlkokul & 27 & 17.8 \\
& Ortaokul & 8 & 15.6 \\
& Lise & 7 & 2.2 \\
\hline Baba Öğrenim Durumu & Lisans & 1 & 4.4 \\
\hline & Diğer & 2 & 46.7
\end{tabular}




\begin{tabular}{llcr}
\hline & Ortaokul & 9 & 20.0 \\
& Lise & 10 & 22.2 \\
& Lisans & 5 & 11.1 \\
\hline \multirow{3}{*}{ Kardeş Sayısı } & Yok & 1 & 2.2 \\
& Bir & 14 & 31.1 \\
& İki & 15 & 33.3 \\
& Üç & 7 & 15.6 \\
\hline Toplam & Dört ve üzeri & 8 & 17.8 \\
\hline
\end{tabular}

Tablo 1 incelendiğinde araştırmaya katılan öğretmen adaylarının çoğunun meslek lisesi ve Anadolu lisesinden mezun olduğu (\%40), öğretmen adaylarının annelerinin çoğunlukla ilkokul (\%60), babalarının çoğunlukla ilkokul (\%46.7) mezunu oldukları ve çoğu öğretmen adayının iki kardeş (\%33.3) ya da bir kardeşe (\%31.1) sahip olduğu anlaşılmaktadır.

\section{Veri Toplama Araçları}

Araştırmada veri toplama aracı olarak ilgili alan yazın taranarak araştırmacılar tarafindan belirlenen görüşme soruları (nicel ve nitel değerlendirmeye uygun sorular) ve katılımcılara dair demografik bilgilerin edinilmesi amacıyla kişisel bilgi formu kullanılmışıır. Araştırmacılar tarafından hazırlanan kişisel bilgi formunda öğretmen adaylarının cinsiyeti, mezun oldukları lise türü, anne ve baba öğrenim durumu ile kardeş sayısına ilişkin sorular yer almaktadır. Araştırmacılar tarafından hazırlanan görüşme soruları ise; öğretmen adaylarının (1) çocuk haklarına ilişkin bilgi durumu, (2) çocuk haklarının gözetildiği düşünülen reklamlar ve bu reklamlarda yer aldığı tahmin edilen çocuk hakkının belirlenmesi, (3) en sevilen reklamın çocuk haklarını koruması açısından değerlendirilme durumu, (4) reklamlarda korunabilecek çocuk haklarına ilişkin öneri durumlarını değerlendirmeyi hedefleyen toplam 14 soru yer almaktadır. Her bir bölümde yer alan sorular kendi içinde nicel ve nitel değerlendirme yapma imkanı sunacak yani sayısal değerlerle birlikte öğretmen adaylarının görüşlerini de ifade edecek biçimde tasarlanmıştır. İlgili görüşme formu; okul öncesi eğitim alanında çalışan ve çocuk hakları konusunda çalışmaları bulunan üç alan uzmanının görüşlerine sunulmuştur. Uzman görüşlerinin alınmasının ardından önerilen düzenlemeler yapılmıştır. Araştırmacılarca son hali oluşturulan ölçeğin pilot uygulaması üç öğretmen adayı ile gerçekleştirilmiş ve ölçme aracında yer alan görüşme sorularının anlaş1lır olduğu sonucuna ulaşılmıştır. 


\section{İşlem}

Araştırmanın verileri, katılımcı gruba ilgili soruların yer aldığı çevrimiçi formların, mobil uygulamalar ve elektronik posta aracılığıyla (katılımcının tercihine uygun olarak) ulaştırılması ile toplanmıştır. Verilerin toplanması sürecinde katılımcılara araştırmacılarla paylaştıkları bilgilerin yalnızca bilimsel amaçlı olarak kullanılacağına dair etik unsurlar hakkında bilgi verilmiştir. Katılımcıların bu konuda sözlü rızaları alınmıştır. Veri toplama aracı olarak kullanılan kişisel bilgi formu ile görüşme formunda yer alan soruların tamamının yanıtlanması ortalama 30 dakika civarında sürmektedir. Gönüllülük esasına dayalı olarak yürütülen çalışmanın katılımcılarına ilgili görüşme formunu yanıtlamaları için bir hafta süre verilmiştir. Öğretmen adayları bir haftalık sürenin sonunda formları çevrimiçi ortamda doldurarak görüşlerini araştırmacılara iletmişlerdir.

\section{Verilerin Analizi}

Araştırmadan elde edilen nicel bulgular sayısal değerler olarak frekans ve yüzde analizleri ile ifade edilmiştir. Bununla birlikte araştırmada yer alan nitel sorular ise içerik analizi gerçekleştirilerek incelenmiştir. Karma yöntemle tasarlanan araştırmada bakış açısı (veri) zenginliği sağlamak üzere elde edilen farklı veri türleri kendi içlerinde analiz edilmiştir. Buna göre frekans ve yüzde analizleri ilgili sorulara verilen yanıt sayılarının değerlendirilerek hesaplanmasıyla elde edilmiştir. Araştırmanın nitel boyutunda yer alan sorularla elde edilen verilerin analizinde ise betimsel bir yaklaşım izlenmiştir. Buna göre katılımcılardan yanıtladıkları nitel sorular incelenirken; çalışma grubunun yaklaşık \%25’inin (11 katılımcı) yanıtları öncelikle üç ayrı kodlayıcı tarafından açık kodlama yapılarak kodlanmıştır. Ardından kodlayıcılar karşılıklı olarak kodlama sonuçlarını incelemişler ve bu kodların nasıl şekillendiğini değerlendirmişlerdir. Yapılan değerlendirmelerde oluşan kodlar üzerinde tartışarak fikir birliğine varmışlardır. Araştırmacıların ortak değerlendirmeleri nihayetinde ortaya çıkan bu fikir birliği kodlamaların geçerliliğinin sağlanması için önemlidir. Varılan fikir birliği doğrultusunda çalışma grubunun \%25’i (11 katılımcının görüşleri) kodlayıcılar tarafından ayrı ayrı kapalı kodlama yöntemiyle değerlendirilmiştir. Yapılan kapalı kodlama nihayetinde kodlayıcıların yaptıkları değerlendirmeler arası uyum Miles ve Huberman katsayısı hesaplanarak incelenmiştir. Buna göre içsel tutarlıllğı ifade eden ve kodlayıcılar arasındaki görüş birliğine dayalı olarak kavramsallaştırılan güvenirlik katsayısı (güvenirlik katsayısı= Üzerinde görüş birliği sağlanan konu/terim sayısı $\div$ (Üzerinde görüş birliği sağlanan konu/terim sayıs1 + Üzerinde görüş birliği sağlanamayan konu/terim sayısı) $\times 100$ formülüne göre hesaplanmıştır. Araştırmada kodlayıcılar arası uyum yüzdesi \%93.71 olarak hesaplanmıştır. Miles ve Huberman (1994) kodlayıcılar arası görüş birliğinin en az \%80 olması gerektiğini ifade etmiştir. Bu bağlamda araştırnada elde edilen 
uyumun yüksek düzeyde olduğu söylenebilir. Araştırmada elde edilen verilerden geriye kalan 23 verinin tamamı varılan görüş birliği doğrultusunda araştırmacılarca paylaşılarak değerlendirilmiştir. Gerçekleştirilen kodlamaların ardından kodlayıcılar bir araya gelerek belirlenen kodların hangi görüş ya da fikirler etrafında kümelendiğini görüşmüşlerdir. Bu kümelenmeler alan yazın ışığında incelenmiş ve bu şekilde kategoriler belirlenmiştir. Meydana gelen kategorilerdeki görüşlerin betimlenmesi ve yorumlanmasında yine frekans, yüzde hesaplamalarına yer verilirken; örnek ifadeler de belirtilmiştir. Araştırma sonucu elde edilen nicel ve nitel yani sayısal bulgular ile derinlemesine görüş ifade eden durumlar bir arada değerlendirilerek araştırma amacına uygun olarak tartışılmıştır.

\section{BULGULAR}

Okul öncesi öğretmen adaylarının ekranda (televizyon ve internet) izlediği reklamlardaki çocuk haklarına ilişkin görüşlerini belirlemeyi amaçlayan araştırmada elde edilen bulgular; (1) çocuk haklarına ilişkin bilgi durumu, (2) çocuk haklarının gözetildiği düşünülen reklamlar ve tahmin edilen çocuk hakkının belirlenmesi, (3) en sevilen reklamın çocuk haklarını koruması açısından değerlendirilme durumu ve (4) reklamlarda korunabilecek çocuk haklarına ilişkin öneri durumlarını değerlendirmeye yönelik olarak ele alınmıştır. Araştırmadan elde edilen bulgulara aşağıda yer verilmiştir.

Tablo 2. Araştırmaya katılan öğretmen adaylarının günlük ekran karşısında geçirdikleri süre frekans ve yüzde dağılımları

\begin{tabular}{lll}
\hline Günlük Ekran Karşısında Geçirilen Süre & $\mathrm{n}$ & $\%$ \\
\hline 30 dakika & 3 & 6.7 \\
1 saat & 1 & 2.2 \\
2 saat & 8 & 17.8 \\
3 saat & 12 & 26.7 \\
4 saat & 9 & 20.0 \\
5 saat & 5 & 11.1 \\
saat ve üzeri & 7 & 15.6 \\
\hline Toplam & 45 & 100.0 \\
\hline
\end{tabular}

Tablo 2 incelendiğinde öğretmen adaylarının en yüksek oranla günlük 3 saatlerini (\%26.2) ekran karşısında geçirdikleri, bunu günlük 4 saat (\%20.0), 2 saat (\%17.8) ve 6-üzeri saat (\%15.6) geçirenlerin takip ettiği anlaşılmaktadır.

Tablo 3. Araştırmaya katılan öğretmen adaylarının çocuk haklarını bilme durumuna ilişkin frekans ve yüzde dağılimları

\begin{tabular}{|c|c|c|c|}
\hline Çocuk Haklarını Bilme Durumu & & $\mathrm{n}$ & $\%$ \\
\hline Evet (Biliyorum) & & 21 & 46.7 \\
\hline Hayır (Bilmiyorum) & & 2 & 4.4 \\
\hline Kusmen Biliyorum & & 22 & 48.9 \\
\hline Toplam & & 45 & 100.0 \\
\hline
\end{tabular}


Tablo 3 incelendiğinde araştırmaya katılan öğretmen adaylarının çocuk haklarını kısmen bildikleri (\%48.9), çocuk haklarını bildiğini ifade edenlerin kısmen bilenleri takip ettiği (\%46.7) ve son çocuk olarak çocuk haklarını bilmediğini ifade eden öğretmen adaylarının olduğu(\%4.4) anlaşılmaktadır.

Tablo 4. Araştırmaya katılan öğretmen adaylarının çocuk haklarıyla ilgili ders alma ya da seminere katılma durumuna ilişkin frekans ve yüzde dağılımları

\begin{tabular}{llc}
\hline Ders ya da Seminer Alma Durumu & $\mathrm{n}$ & $\%$ \\
\hline Evet & 15 & 33.3 \\
Haylr & 30 & 66.7 \\
\hline Toplam & 45 & 100.0 \\
\hline
\end{tabular}

Tablo 4'e göre araştırmaya katılan öğretmen adaylarının çoğunun çocuk haklarıyla ilgili herhangi bir ders almadığı ya da herhangi bir seminere katılmadığ1 (\%66.7), yalnızca üçte birinin (\%33.3) bu konuda ders aldığı ya da seminerlere katıldığı anlaşılmaktadır.

Katılımcıların bildikleri çocuk hakları sorulduğunda ise 16 öğretmen adayı bu soruyu yanıtlamamış olup; yanıt veren 29 öğretmen adayının yanıtları; yaşama, gelişim, korunma ve katılım hakları kategorilerinde değerlendirilmiş ve bulgular Tablo 5’te yer almaktadır.

Tablo 5. Araştırmaya Katılan Öğretmen Adaylarının Bildikleri Çocuk Haklarının Kategorileştirilerek İncelenmesi

\begin{tabular}{|c|c|c|}
\hline Kategori & $\mathrm{f}$ & Örnek \\
\hline Yaşama Hakkı & 51 & $\begin{array}{l}\text { Yaşama, barınma, barış özgürlük içinde yaşama, sağlık, temiz çevre, } \\
\text { sahipsiz çocukları bakmakla devlet yükümlüdür }\end{array}$ \\
\hline Gelişim Hakk1 & 44 & $\begin{array}{l}\text { Ĕ̈itim, özel eğitim, gelişme, dinlenme, oyun, kültürel etkinliklere } \\
\text { katılım, ayrımcllığın önlenmesi, eğlenme, eşit haklar, } 18 \text { yaşına kadar } \\
\text { çocuk olmak, ilgi, ihtiyaç ve yeteneklerine göre eğitim görme }\end{array}$ \\
\hline Korunma Hakkı & 38 & $\begin{array}{l}\text { Korunma, } 18 \text { yaşından önce çalıştırılmama, engelli bireyler, sosyal } \\
\text { güvenlik, kimlik, her türlü sömürüden korunma, ailesiyle birlikte olma, } \\
\text { ilgi sevgi güven içinde olma, şiddet, istismar ve ihmalden korunma, } \\
\text { savaşlardan uzak yaşama, isme sahip olma, güvenli aile ve çevrede } \\
\text { olma, fiziksel psikolojik, cinsel sömürü, çocuk yararı, ebeveynleri } \\
\text { tarafından yetiștirilme }\end{array}$ \\
\hline Katılım Hakk1 & 13 & $\begin{array}{l}\text { Düşünce, ifade özgürlüğü, katılım, duygularını rahatça ifade etme, } \\
\text { kararlara katılma, sosyalleşme hakkı, kendini ilgilendiren konularda } \\
\text { düşüncelerini söyleme }\end{array}$ \\
\hline Cevap Yok & 16 & - \\
\hline
\end{tabular}

Tablo 5 incelendiğinde araştırmaya katılan öğretmen adaylarının yaklaşık olarak üçte birinin, bildikleri çocuk haklarının neler olduğuna dair herhangi bir yanıt vermediği görülmektedir. Bildiği çocuk haklarına ilişkin yanıtlar veren 29 öğretmen adayının ise en çok örnekler verdiği çocuk hakkı yaşama hakkı kategorisine aittir ( $\mathrm{f}=51)$, bunu sırasıyla gelişim hakkı ( $\mathrm{f}=44)$, korunma hakkı $(\mathrm{f}=38)$ ve en az sayıda yanıtın geldiği katılım hakkı (f=13) takip etmektedir. Katılım hakkının diğer kategorilerde yer alan ifadelere göre en az sayıda yanıt verilen kategori olduğu görülmektedir. Katılımcılara reklamların çocuk haklarını dikkate alma durumu, çocuk haklarının gözetildiğini 
düşündükleri reklamlar ve bu reklamlarda korunduğunu düşündükleri çocuk haklarının neler olduğuna ilişkin görüşleri sorulmuştur. Elde edilen bulgular Tablo 6 ve 7'de yer almaktadır.

Tablo 6. Araştırmaya katılan öğretmen adaylarının reklamların çocuk haklarını dikkate alma durumuna ilişkin görüşlerinin frekans ve yüzde dağılımları

\begin{tabular}{lcc}
\hline Reklamların Çocuk Haklarını Dikkate Alması Durumuna İlişkin Görüş & $\mathrm{n}$ & $\%$ \\
\hline Evet dikkate alıyor & 2 & 4.4 \\
Hayır dikkate almıor & 24 & 53.3 \\
Kısmen & 19 & 42.2 \\
\hline Toplam & 45 & 100.0 \\
\hline
\end{tabular}

Tablo 6'ya göre araştırmaya katılan öğretmen adaylarının çoğu ekranda izledikleri reklamların çocuk haklarını dikkate almadığını (\%53.3), bunu kısmen dikkate aldığını düşünenlerin (\%42.2) takip ettiği ve reklamların çocuk haklarını dikkate aldığını düşünenlerin en az sayıda katılımcı olduğu (\%4.4) görülmektedir.

Tablo 7. Araştırmaya katılan öğretmen adaylarının çocuk haklarının gözetildiğini düşündükleri reklamlar ve bu reklamlarda korunan çocuk haklarının kategorileştirilerek incelenmesi

\begin{tabular}{|c|c|c|c|c|c|c|}
\hline \multicolumn{3}{|c|}{ İnternette izlenen reklamlar } & \multicolumn{4}{|c|}{ Televizyonda izlenen reklamlar } \\
\hline Kategori & $\mathrm{f}$ & İçerik & $\begin{array}{l}\text { Korunan } \\
\text { Çocuk Hakk1 }\end{array}$ & $\mathrm{f}$ & İçerik & $\begin{array}{l}\text { Korunan } \\
\text { Çocuk Hakk1 }\end{array}$ \\
\hline $\begin{array}{l}\text { Kamu spotu } \\
\text { reklamlar }\end{array}$ & 2 (Ö18,Ö5) & $\begin{array}{l}\text { Beslenme, } \\
\text { eğitim, } \\
\text { sağlık }\end{array}$ & $\begin{array}{l}\text { Yaşam H. } \\
\text { Gelişim H. }\end{array}$ & 2 (Ö42,Ö32) & $\begin{array}{l}\text { Çevre, } \\
\text { eğitim, } \\
\text { sağllk }\end{array}$ & $\begin{array}{l}\text { Yaşam H. } \\
\text { Gelişim H. } \\
\text { Korunma H }\end{array}$ \\
\hline $\begin{array}{l}\text { STK (Unicef, } \\
\text { Lösev, Tegev }\end{array}$ & $\begin{array}{l}8(\text { (Ö1,Ö5, } \\
\text { Ö6,Ö10,Ö } \\
\text { 15,Ö18,Ö3 } \\
\text { 2) }\end{array}$ & $\begin{array}{l}\text { Dünya } \\
\text { çocuk } \\
\text { hakları, } \\
\text { beslenme, } \\
\text { kişisel } \\
\text { bakım }\end{array}$ & $\begin{array}{l}\text { Yaşam H. } \\
\text { Korunma H. }\end{array}$ & 2 (Ö10,Ö32) & $\begin{array}{l}\text {-Eğitim ve } \\
\text { Çocuk } \\
\text { Sağllğ }\end{array}$ & $\begin{array}{l}\text { Yaşam H. } \\
\text { Gelişim H. }\end{array}$ \\
\hline Şirketler & $\begin{array}{l}11 \text { (Ö2,Ö5, } \\
\ddot{O} 12, \ddot{O} 13, \\
\text { Ö15,Ö30, } \\
\text { Ö32,Ö38, } \\
\text { Ö39,Ö43, } \\
\text { Ö45) }\end{array}$ & $\begin{array}{l}23 \text { Nisan, } \\
\text { çevre } \\
\text { sürdürülebil } \\
\text { irlik, } \\
\text { beslenme } \\
\text { eğitim }\end{array}$ & $\begin{array}{l}\text { Yaşam H. } \\
\text { Gelişim H. } \\
\text { Korunma H. }\end{array}$ & $\begin{array}{l}7 \\
\text { (Ö6,Ö30,Ö3Ö } \\
\text { 2,Ö39,Ö43, Ö4 } \\
\text { 4,Ö45) }\end{array}$ & $\begin{array}{l}\text { Eğitim, } \\
\text { beslenme, } \\
\text { kişisel } \\
\text { bakım }\end{array}$ & $\begin{array}{l}\text { Yaşam H. } \\
\text { Gelişim H. }\end{array}$ \\
\hline Yok & 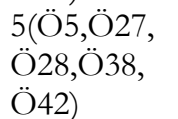 & - & & - & & \\
\hline
\end{tabular}

Tablo 7'ye göre araştırmaya katılan öğretmen adaylarından çocuk haklarının gözetildiğini düşündükleri internet ve televizyon reklamları aynı dört kategoride incelenmiştir. Buna göre öğretmen adaylarının internet reklamlarında çocuk haklarının en çok korunduğunu düşündükleri reklam çeşitli şirketler tarafından yayınlanan 23 Nisan, çevre, sürdürülebilirlik, beslenme ve eğitim içerikli reklamlar olup bu reklamlarda korunan çocuk haklarının yaşama, gelişim ve korunma hakları olduğunu belirtmişlerdir ( $\mathrm{f}=11$ ). Bunu Sivil Toplum Kuruluşları tarafından yayınlanan Dünya Çocuk Haklarına dair, beslenme ve kişisel bakıma dair reklamlar; yaşama ve korunma hakları ile takip etmektedir $(\mathrm{f}=8) .5$ öğretmen adayı internette yayınlanan ve çocuk haklarını gözeten bir 
reklam olmadığını ifade ederken; En az yanıtın verildiği kategori ise kamu spotlarıdır. Kamu spotlannda da beslenme, eğitim ve sağlı̆̆a yer verildiğini; bunların yaşama ve gelişim hakları ile ilişkili olduğunu ifade etmişlerdir ( $\mathrm{f}=2$ ).

Öğretmen adaylarının televizyonda izledikleri reklamlarda çocuk haklarının gözetildiğini düşündükleri reklam kategorileri arasında en çok yanıt verdikleri kategori; internet reklamlarında da olduğu gibi, şirketler tarafindan yayınlanan reklamlar olmuştur. Bu reklamların içeriklerinin eğitim, beslenme ve kişisel bakım olduğu; yaşama ve gelişim hakkını koruduğunu ifade etmişlerdir $(\mathrm{f}=7)$. Bunu kamu spotları, çevre, eğitim ve sağlık içerikli reklamlar ile yaşama, gelişim ve korunma haklarını koruyarak $(\mathrm{f}=2)$; sivil toplum kuruluşlarına ait reklamlar ise eğitim ve çocuk sağlığ1 içerikleri ile yaşama ve gelişim haklarını koruyarak takip etmektedir ( $\mathrm{f}=2$ ).

Tablo 8. Araştırmaya katılan öğretmen adaylarının çocuk haklarının gözetilmediğini düşündükleri reklamlar ve bu reklamlarda korunmayan çocuk haklarının kategorileştirilerek incelenmesi

\begin{tabular}{|c|c|c|c|c|c|c|c|}
\hline \multicolumn{4}{|c|}{ İnternette izlenen reklamlar } & \multicolumn{4}{|c|}{ Televizyonda izlenen reklamlar } \\
\hline Kategori & $\mathrm{f}$ & İçerik & $\begin{array}{l}\text { Korunan } \\
\text { Çocuk } \\
\text { Hakkı }\end{array}$ & Kategori & $\mathrm{f}$ & İçerik & $\begin{array}{l}\text { Korunan } \\
\text { Çocuk } \\
\text { Hakk1 }\end{array}$ \\
\hline $\begin{array}{l}\text { Digital } \\
\text { Oyunlar }\end{array}$ & $\begin{array}{l}4 \\
\text { (Ö1,Ö7, } \\
\text { Ö38,Ö42 } \\
\text { ) }\end{array}$ & Momo & $\begin{array}{l}\text { Korunma } \\
\text { H. }\end{array}$ & Oyuncaklar & $\begin{array}{l}2 \\
(\ddot{\mathrm{O}} 17, \mathrm{O} 3 \\
8)\end{array}$ & $\begin{array}{l}\text { Barbie, } \\
\text { dijital } \\
\text { oyunca } \\
\text { klar }\end{array}$ & $\begin{array}{l}\text { Gelişim H } \\
\text { Korunma } \\
\text { H. }\end{array}$ \\
\hline $\begin{array}{l}\text { Gelişime } \\
\text { uygun olmayan } \\
\text { performans }\end{array}$ & $\begin{array}{c}2 \\
(\ddot{\mathrm{O}} 1, \mathrm{O} 2)\end{array}$ & $\begin{array}{l}\text { Hiz- yarış } \\
\text { kazanma, } \\
\text { bebeğin } \\
\text { akrobatik } \\
\text { hareketleri }\end{array}$ & Gelişim H. & & & & \\
\hline Kişisel Bakım & $\begin{array}{l}2 \\
(\mathrm{O} 5, \mathrm{O} 13)\end{array}$ & $\begin{array}{l}\text { Deterjan, } \\
\text { bebek bezi }\end{array}$ & $\begin{array}{l}\text { Gelişim, } \\
\text { Korunma } \\
\text { H }\end{array}$ & $\begin{array}{l}\text { Kişisel } \\
\text { Bakım }\end{array}$ & $\begin{array}{l}2 \\
(\ddot{O} 42, \ddot{O} 1 \\
3)\end{array}$ & $\begin{array}{l}\text { Bebek } \\
\text { bezi, } \\
\text { pişik } \\
\text { kremi }\end{array}$ & Yaşam H. \\
\hline Beslenme & $\begin{array}{l}2 \\
(\ddot{O} 45, \ddot{O} 5)\end{array}$ & $\begin{array}{l}\text { Fast food } \\
\text { yiyecekler, } \\
\text { kola, çikolata, } \\
\text { dondurma }\end{array}$ & Yaşam H & & & & \\
\hline Diğer & $\begin{array}{l}3 \\
\text { (Ö30, Ö6, } \\
\text { Ö42) }\end{array}$ & $\begin{array}{l}\text { Youtube } \\
\text { Yapay zeka, } \\
\text { tanışma } \\
\text { oyunları }\end{array}$ & $\begin{array}{l}\text { Gelişim, } \\
\text { Korunma } \\
\text { H }\end{array}$ & Diğer & 1(Ö30) & $\begin{array}{l}\text { Şiddet } \\
\text { karşıtı } \\
\text { reklaml } \\
\text { ar }\end{array}$ & $\begin{array}{l}\text { Korunma } \\
\mathrm{H}\end{array}$ \\
\hline Yok & 1(Ö32) & & & Yok & 1(Ö32) & & \\
\hline
\end{tabular}

Tablo 8 incelendiğinde araştırmaya katılan öğretmen adaylarının çocuk haklarının gözetilmediğini düşündükleri internet ve televizyon reklamları farklı kategorilerde incelenmiştir. Buna göre öğretmen adaylarının internet reklamlarında çocuk haklarının çoğunlukla gözetilmediğini düşündükleri reklamlar dijital oyunlar kategorisinde yer alan Momo adlı oyunun reklamı ile korunma hakkının ihlal edildiği yönündedir $(\mathrm{f}=4)$. Bunu takiben diğer kategorisinde yer alan video paylaşım kanalı youtube'nin, yapay zeka ve tanışma oyunları içeriklerinin yaşama hakkını 
gözetmediğini belirtmişlerdir ( $\mathrm{f}=3$ ). Gelişime uygun olmayan performans kategorisinde yer alan hız-yarış kazanma, bebeğin akrobatik hareketleri içeriklerine sahip reklamların gelişim hakkını (f=2); kişisel bakım reklamları kategorisindeki deterjan ve bebek bezi içerikli reklamların gelişim ve korunma hakkını $(\mathrm{f}=2)$; beslenme kategorisinde fast food yiyecekler, kola, çikolata, dondurma içerikli reklamların yaşama hakkını gözetmediğini belirtmişlerdir ( $\mathrm{f}=2$ ). Bir öğretmen adayı böyle bir reklamın olmadığı görüşündedir.

Öğretmen adaylarının çocuk haklarının gözetilmediğini düşündükleri televizyon reklamlarında sıklıkla yanıt verilen kategorilerin oyuncaklar ve kişisel bakım olduğu $(\mathrm{f}=2)$ anlaşılmaktadır. Oyuncaklar kategorisinde yer alan Barbie ve dijital oyuncakların, gelişim ve korunma hakkını ihlal ettiği; kişisel bakım kategorisinde bebek bezi ve pişik kremi içerikli reklamların yaşama hakkını ihlal ettiğini belirtmişlerdir. Bir öğretmen adayı diğer kategorisinde yer alan şiddet içerikli reklamları korunma hakkı ihlali nedeniyle uygun görmediğini belirtirken bir öğretmen adayı da böyle bir reklamın olmadığını belirtmiştir.

Tablo 9. Araştırmaya Katılan Öğretmen Adaylarının En Sevdikleri Reklamın Çocuk Haklarını Dikkate Alması Durumuna İlişkin Görüşlerinin Frekans ve Yüzde Dağılımları

\begin{tabular}{lll}
\hline En Sevdikleri Reklamın Çocuk Haklarını Dikkate Alması Durumuna İlişkin Görüşler & $\mathrm{n}$ & $\%$ \\
\hline Evet dikkate alıyor & 17 & 37.7 \\
Hayır dikkate almıyor & 8 & 17.8 \\
Kımen & 20 & 44.4 \\
\hline Toplam & 45 & 100.0 \\
\hline
\end{tabular}

Tablo 9 incelendiğinde araştırmaya katılan öğretmen adaylarının ekranda izledikleri ve en sevdikleri reklamı çocuk haklarını dikkate alması durumuna göre değerlendirdiklerinde çoğunluğun en sevdikleri reklamın çocuk haklarını kısmen dikkate aldığını (\%44.4), bunu dikkate aldığını düşünenlerin (\%37.7) takip ettiği ve en sevdiği reklamın çocuk haklarını dikkate almadığını düşünenlerin en az sayıda katılımcı olduğu (\%17.8) belirlenmiştir.

Tablo 10. Araştırmaya katılan öğretmen adaylarının en sevdikleri reklamın kategorileştirilerek incelenmesi

\begin{tabular}{|c|c|c|}
\hline Kategori & $\mathrm{f}$ & Örnek \\
\hline Çevre & 2 & Doğayı Koruma, Finish yarının suyu için söz \\
\hline Kutlama/ hediyeler & 4 & $\begin{array}{l}\text { Vestel, } 23 \text { Nisan Çocuk bayramı, İş Bank kitap hediyesi, Joker } \\
\text { Baby babalar günü }\end{array}$ \\
\hline Yiyecek içecek & 6 & $\begin{array}{l}\text { Pınar Süt, Eti, Milupa organik-Ali’nin karnı acıktı, dondurma } \\
\text { reklamları }\end{array}$ \\
\hline Spor & 3 & Turkcell, Anadolu Efes, Nike (What are girls made of) \\
\hline Kamu Spotu & 1 & Kamu spotu \\
\hline STK & 1 & Lösev \\
\hline
\end{tabular}

Tablo 10 incelendiğinde araştırmaya katılan öğretmen adaylarının en çok sevdikleri reklamların yiyecek içecek reklamları kategorisinde $(\mathrm{f}=6)$, ardından kutlama/hediyeler kategorisinde $(\mathrm{f}=4)$ spor kategorisinde $(\mathrm{f}=3)$, çevre kategorisinde $(\mathrm{f}=2)$ ve en az olarak kamu spotları ile sivil toplum 
kuruluşları kategorilerine (f=1) ait reklamlar olduğu anlaşılmaktadır. Şekil 1'de öğretmen adaylarının reklamlar yoluyla çocuk haklarının korunabilirliğine ilişkin görüssleri yer almaktadır.

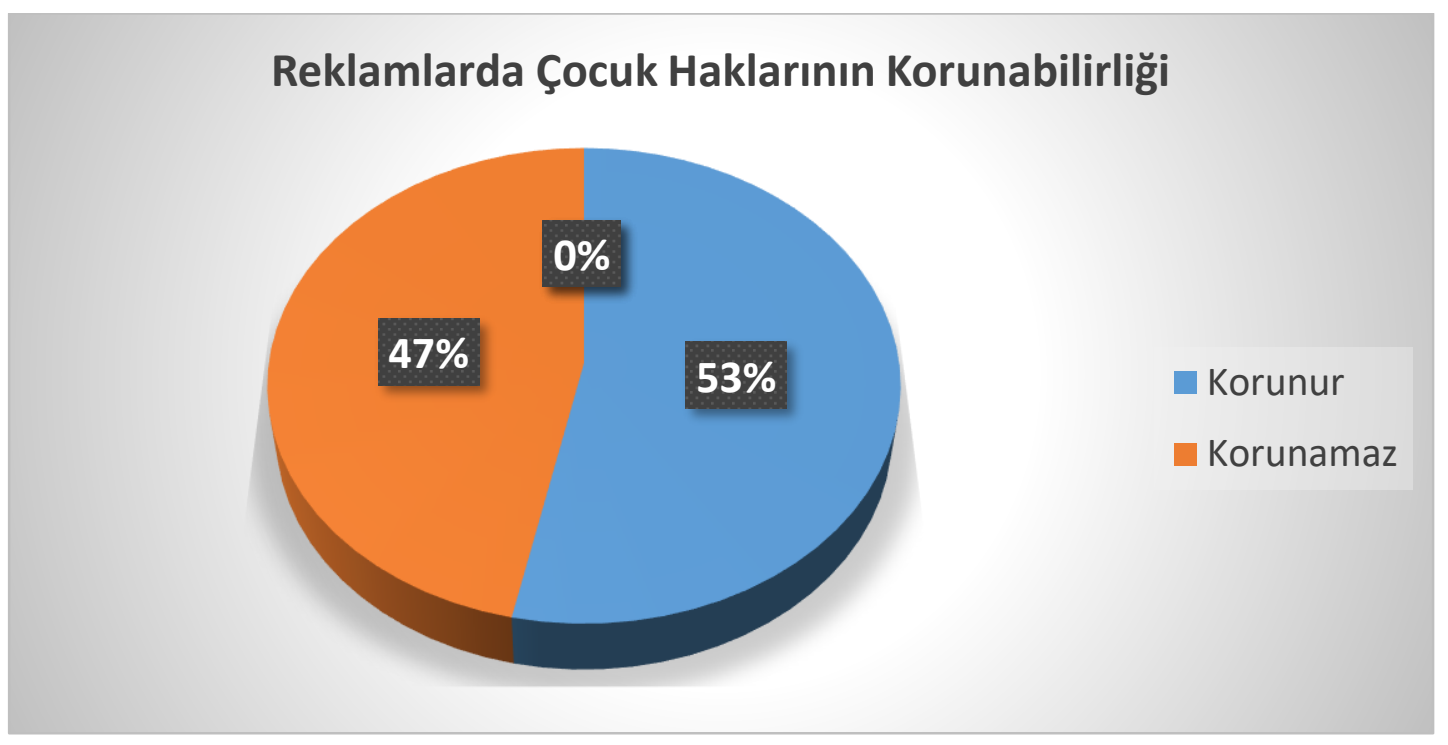

Şekil 1. Katılımcıların Reklamlarda Çocuk Haklarının Korunabilirliğine İlişkin Görüşleri

Şekil 1'e göre araştırmaya katılan 24 öğretmen adayı (\%53) reklamlarda çocuk haklarının korunabileceğini düşünürken; 21 öğretmen adayı (\%47) ise reklamlarda çocuk haklarının korunamayacağını ifade etmişlerdir. Öğretmen adaylarının reklamlarda korunabileceğini belirttikleri çocuk hakları kategorileri Tablo 11'de yer almaktadır.

Tablo 11. Araştırmaya katılan öğretmen adaylarının reklamlarda korunabileceğini belirttikleri çocuk haklarının kategorileştirilerek incelenmesi

\begin{tabular}{|c|c|c|}
\hline Kategori & $\mathrm{f}$ & Örnek \\
\hline Yaşama Hakk1 & 19 & $\begin{array}{l}\text { Sağlık, yaşam, barınma, ruh sağlığı bozulmaması, beslenme, sağlıklı yaşam, } \\
\text { bütün çocuklar içindir }\end{array}$ \\
\hline Gelişim Hakkı & 21 & $\begin{array}{l}\text { Oyun, eğlenme, yardımlaşma, geliş̧im, eğitim, çocuk olma, ayrımcılığın } \\
\text { önlenmesi, eşit olma, oyuncakları almaya teşvik etmemeli, }\end{array}$ \\
\hline Korunma Hakk1 & 19 & $\begin{array}{l}\text { Yardım, ailenin sevgisi, kötülükler koruma, mahremiyet, güvenlik, bireysel } \\
\text { sınırlar, korunma, çalıştırılmamam, özel hayatın sergilenmemesi, } \\
\text { istismardan korunma, fiziksel cinsel sömürü, siddet, engelli çocuklar }\end{array}$ \\
\hline Katılım Hakk1 & 5 & Düşüncelerini özgürce ifade etme, din-vicdan özgürlüğü \\
\hline
\end{tabular}

Tablo 11'e göre araştırmaya katılan öğretmen adaylarının reklamlarda korunabileceğini belirttikleri çocuk haklarının çoğunlukla gelişim hakkı kategorisinde ( $\mathrm{f}=21$ ), oyun, eğlenme, yardımlaşma gibi örneklerle açıklandığı görülmektedir. Bunu yaşama hakkının ( $\mathrm{f}=19)$, sağlık yaşam, barınma gibi örneklerle ve korunma hakkının ( $\mathrm{f}=19$ ) yardım, aile sevgisi, kötülüklerden koruma gibi örneklerle takip ettiği belirlenmiştir. Öğretmen adaylarının reklamlarda en az korunabileceğini ifade ettikleri çocuk hakları katılım hakkı ( $\mathrm{f}=5)$ kategorisinden, düşüncelerini özgürce ifade etme ve din-vicdan özgürlüğü örnekleri ile açıklanmıştır. 


\section{SONUÇ ve TARTIŞMA}

Araştırma bulgusu olarak öğretmen adaylarının günlük üç saatlerini ekran karşısında geçirdikleri belirlenmiştir. Bu durum çağın dışında bir uygulama değildir. Dünya çapında yapılan bir araştırmada Y kuşağının \%90'nının uyumaya gitmeden önce sosyal medya hesaplarını, maillerini akıllı telefonlarından kontrol ettiklerini ortaya koymuştur (Anonim 2019). İnternet, insanlar tarafindan eğlenme, iş seyahat, arkadaş edinme gibi birçok amaçlı kullanılmakta, ayrıca internet aracıllğ̆yla yapılan reklamların klasik reklamlardan farklı olması izleyicileri daha çok etkilemektedir. Hatta pek çok reklam arasından sıyrılarak tüketicinin dikkatini çekmek ve kalıcıllğı sağlayabilmek amacıyla reklamlarda sıra dışı gösterimleri kullanarak, reklam verenler ve reklam ajansları etik dışı unsurları kullanabilmektedirler (Yaman 2009; Yilmazsoy ve Kahraman, 2017; Yeşil ve Fidan, 2017). Araştırma bulgusunu destekler nitelikte olan bu açıklamalar öğretmen adaylarının da ekran karşısında geçirdikleri süre zarfında reklamlarla karşılaştıklarının kanıtı olarak düşünülmektedir (Anonim 2019). Ayrıca reklamların içerikleri ve olumsuz etkileri olabileceği düşüncesiyle bilinçli kullanım konusunda eğitim gerekliliği ortaya çıkmaktadır.

Araştırmaya katılan öğretmen adayları çocuk haklarını öncelikle kısmen ve onu takiben de biliyorum diyerek çocuk haklarına dair bilgiye sahip olduklarını belirtmişlerdir. Leblebici ve Çeliköz (2017), Covell ve Howe (1995), Karaman Kepenekçi (2006) ve Değirmenci’nin (2011), araştırmalarında belirttiği gibi çocuk hakları sözleşmesini okumuş öğrenmiş olmanın okul öncesi öğretmen adaylarının çocuk haklarına yönelik tutumlarını olumlu yönde etkileyeceğinden bu önemli bir bulgudur. Okul öncesi öğretmen adaylarının çocuk haklarını kısmen bildiklerini belirtmeleri öğretmen adaylarının bu konuda yeterli özgüvene sahip olmadıkları şeklinde de yorumlanabilir. Kısmen bilmek de okul öncesi öğretmen adaylarının çocuk haklarını yetersiz bilmeleri anlamına gelmektedir. Oysa okul öncesi öğretmenlerinin çocuk merkezli bir şekilde, diyalog ve örneklerle, çocukların haklarını uygulama yeteneklerini arttıran, "yol göstericilik ve yönlendirme" rolleriyle, çocuklardan sorumlu temel kişi olmalarından dolayı, çocuk hakları uygulamalarına ne derece bildiği önemlidir (Koran 2012). Kısmen bilgiye sahip olmalar1 Koran (2012) ve Tozduman Yaralı ile Güngör Aytar’’n (2017) çalısmalarında okul öncesi öğretmenlerin katılım hakları konusunda yeterli bilgiye sahip olmadıkları bulgusu ile benzerlik göstermektedir. Banko (2017) okul öncesi öğretmenlerinin çocuk haklarına yönelik tutumlarının yüksek olduğunu, sınıf içindeki uygulamalarında çocuk haklarına uygunluklarına yönelik görüş ve davranışlarının istenilen düzeyde olmadığını, Hareket (2019) Temel Eğitim Bölümü öğrencilerinin çocuk hakları konusundaki algılarının ve farkındalık durumlarının geliştirilmesi gerektiğini belirtmiştir. Neslitürk ve Ersoy (2007) çalışmalarında çocuk haklarına ilişkin öğretmen adaylarının düzeye uygun etkinlikler 
verilebileceğini düşünmelerine karşın etkinlik hazırlamayı zor olarak ifade ettiklerini belirtmişlerdir. $\mathrm{Bu}$ araştırma sonucunda çocuk haklarını bilmelerine karşın çocuk haklarını kısmen biliyoruz olarak ifade etmelerinin bir nedeni olarak da çocuk haklanna yönelik etkinlikler hazırlamayı zor olarak görmelerinden kaynaklandığı düşünülebilir. Buradan çocuk hakları öğretiminin somutlaştırılması, yeterli bilgi ve becerilerle donatılma gerekliliği sonucu çıkarılabilir. Ancak bu şekilde uygulamanın içine girmeden öğretmen adaylarının çocuk hakları konusunda bir tutuma sahip olmaları sağlanarak tutumları mesleki deneyim ile daha da güçlenecektir.

Araştırmaya katılan öğretmen adaylarının üçte biri çocuk hakları konusunda ders almış ya da seminerlere katılmıştır. Çocuk haklarına ilişkin öğretmen adaylarının ders alma ve sözleşmeyi okuma durumu, çocuk haklarına ilişkin düzenlenen çalışmalara katılmaları çocuk haklarına yönelik tutumlarını olumlu yönde etkiler (Covell ve Howe, 1995; Değirmenci, 2011; Karaman Kepenekçi, 2006) bulgularının aksine Yaşar Ekici (2014) ile Platin ve Ahmetoğlu (2020) çalışmalarında ise herhangi bir etki belirlenmemiştir. Çocuk Hakları Sözleşmesi’nde yer alan bütün hükümlerin herkes tarafından öğrenilmesi öngörülmektedir. Bu durumda çoğunluğun ders ve seminer almaması öğretmen adaylarının daha sonra alacakları dersleri seçerken içerikleri ile ilgilenerek çocuk hakları ile ilgili derslere yönelirlerse öğretmen adaylarının farkındalıklarının olumlu yönde etkilenerek artacă̆ı yargısına varılabilir.

Mevcut araştırmadan elde edilen bir diğer bulgu, öğretmen adaylarının üçte birinin bildikleri çocuk haklarına ilişkin yanıt vermemeleri ile birlikte en çok yaşam ve gelişim hakkını, sonra korunma hakkını ve en az da katılım hakkını bildiklerini belirtmeleridir. Öğretmen adaylarının reklamlarda korunabileceğini düşündüğü haklar da bu sonuçla paraleldir. Kozikoğlu (2017) okul öncesi öğretmenlerin çocuk hakları denilince daha çok yaşamsal haklar, gelişme hakları, korunma hakları ve katılım haklarına vurgu yaptıklarını belirlemiştir. Kop ve Tuncel (2010), Kaya (2011), Özkan (2013) çalışmalarında bilinen haklar olarak yaşama ve gelişim haklarını vurgularken, Kardeş Banko, Eren ve Antakyalıoğlu (2017), Sop ve Topçu Bilir ( 2021) ise özellikle katılım hakkı konusuna öğretmen adaylarının istenilen düzeyde bilgi sahibi olmadıklarını saptamışlardır. Olsson’ in (2020) öğretmen adayları için çocuk haklarıyla ilgili bilginin önemli olduğu kabul edilse de, müfredatın öğretmen adaylarının hangi bilgiye ihtiyaç duyduğu konusunda çok az rehberlik sağladığına ilişkin görüşüne paralel olarak öğretmen eğitim program içeriklerinde çocuk haklarının yer alma durumunun da etkili olduğunu düşündürmektedir. Görüldüğü gibi çalışma farklı araştırma bulguları ile desteklenmektedir. Çalışmada katılım hakkına öğretmen adaylarınca reklam içeriklerinde de yer verilmemesi teorikte bilinen hakkıın uygulamaya aktarılamadığı ya da bilince yerleşmediği şeklinde yorumlanabilir. 
Araştırmaya katılan öğretmen adaylarının çoğu ekranda izledikleri reklamların çocuk haklarını dikkate almadığını (\%53.3) ve kısmen dikkate aldığını (\%42.2) ifade etmişlerdir. Bu durum çocukların reklamları nasıl algıladıklarını anlamaya çalışmak için çocuk yararı ve hakları açısından reklamların incelenmesi gerektiğini göstermektedir. Çünkü televizyon izleme süreleri çocukların algılarını etkilemekte, televizyon bir davranışı gösterdiğinde bu davranışı yapmaya yönelik olarak bireyi harekete geçirebilmektedir. Yine çocuğun inanç ve davranış gelişiminde, dünyada kadın ya da erkek olmanın ne anlama geldiğini anlamada televizyon önemli bir role sahiptir. Çocukların televizyondan gördükleri ve uyguladıkları en temel davranışlar toplumsal cinsiyete ve şiddete dair davranışlardır (Alabay ve Yağan Güder, 2018). Bu nedenle çocukların saatler boyunca izledikleri programların içeriği her ne olursa olsun bu süre zarfinda mutlaka reklamları da izlemek durumunda kaldıkları düşünülürse izlenen reklamların çocuk hakları açısından uygun olup olmaması ve çocuğu etkileyeceği öğretmen adayları tarafından düşünülmektedir. Başka bir açıdan bakıldığında Boztepe (2018) reklamların toplumsal işlevler üzerinde etkili olduğunu belirtmiştir. Toplumda var olan değerleri pekiştirme ve değiştirmenin, reklamların yeni işlevleri arasında olduğu düşünüldüğünde reklamlarda çocuk haklarının vurgulanması gereklidir. Toplumsal gelişim çerçevesinde çocuk haklarının gözetildiği reklamlara ihtiyaç vardır.

Araştırmada öğretmen adaylarının görüşlerinin alındığı bir başka konu ise internet ve televizyonda izledikleri reklamlarda çocuk haklarının gözetildiğini düşündükleri reklam kategorilerinin ne olduğudur. Katılımcıların en çok yanıt verdikleri kategori şirketler tarafindan yayınlanan reklamlar olup; bu reklamlarda korunan çocuk haklarının yaşama, gelişim ve korunma hakları olduğunu belirtmişlerdir. Bunu internet reklamlarında Sivil Toplum Kuruluşları tarafından yayınlanan Dünya Çocuk Haklarına dair, beslenme ve kişisel bakıma dair reklamlar; yaşama ve korunma hakları ile takip etmekte, televizyondaki reklamlarda bunu kamu spotları çevre, eğitim ve sağlık içerikli reklamlar ile aynı hakları korumakta, internet reklamlarında en az yanıtın verildiği kategori kamu spotlanında da beslenme, eğitim ve sağllğga yer verildiğgi bunların yaşama ve gelişim hakları ile ilişkili olduğu ifade edilmiştir. Televizyon reklamlarında ise en az sayıda sivil toplum kuruluşlarına ait reklamların eğitim ve çocuk sağlığı içerikleri ile yaşama ve gelişim haklarını koruduğu görülmektedir. Kop ve Tuncel (2010) çalışmalarının sonucunda sosyal bilgiler öğretmenlerinin çocuk haklarını genel olarak korunma ve beslenme hakları olarak gördüğü bulgusuna, benzer şekilde araştırmada da yaşam, gelişim ve korunma haklarının içeriklerde yer alması reklamların çocuk hakları konusundaki gerçek durumu betimlediği düşünülebilir. Yine internet ve televizyonda izlenen reklam içeriklerinin benzerliği öğretmen adaylarının izledikleri reklamlardaki çocuk haklarına ilişkin görüşlerinde tutarlı olduklarını düşündürmektedir. 
Okul öncesi öğretmen adaylarının izledikleri reklam içeriklerinde sağlandığını düşündükleri bir diğer çocuk hakkı ise korunma hakkıdır. Bu durumun öğretmen adaylarının koruyucu bir tutumla çocuklara yaklaştıkları için belirttikleri düşünülebilir. Oktay ve Kumbaracıoğlu’nun (2011) öğretmen ve öğrencilerin yani öğretmen adaylarının çocuk haklarına bakışını değerlendirdikleri çalışmalarında hakların önemi ve derecesine ilişkin öğretmenlerin ve öğrencilerin cevaplarının benzer olduğunu ifade etmeleri ve koruyucu tutumla çocukların korunma haklarını vurgulamaları bulgusu ile desteklenebilir. Dumlu (2017) ve Uzun (2018) çocukların korunmasına dair medya bağlamında yapılanları; bir yandan yasalarla gerçekleştirilmeye çalışılırken diğer yandan da ortaya çıkan sorunlara etik kurallarıyla çözüm aranması olarak yorumlamaktadır. Türkiye'de çocuklara ilişkin çocukları korumaya yönelik genel ilkeler geliştirilse de bu ilkelerin yetersiz kaldığını ifade etmektedirler. Reklamlarda olağan durum ve olgular çarpıtılmakta, doğal olan şeylerin imaları kaydırılmakta ve gerçeklik yeniden inşa edilerek, çocuklara ürünün özendiriciliği yapılarak, ailelerin de o ürünü dolaylı olarak alması amaçlanabilmektedir. Reklama ve ürüne cazibe katılması için çocuklar, şirin, güzel ve bakımlı bireyler olarak konumlandırılmakta, yetişkinlere yardım ulaştırabilecek donanımda olan bireylermiş gibi gösterilmekte, çocuğun temsil ediliş şekli ve reklamlarda çocuk kullanımları, çocuğu istismar etmenin bir başka boyutunu gündeme getirmektedir. Bu yüzden reklamda çocuk temsili ve kullanımı sorunlarını ortadan kaldırmak adına günümüz koşulları ile uyumlu olan yeni kararlar alınmalıdır (Dumlu, 2017; Uzun, 2018). Mevcut düzenlemelerle ilgili olarak uygulamada karşılaşılan yetersizlik ve aksaklıkların saptanma ihtiyacı vardır. Belirsizlik içeren ya da boşlukta kalan alanlar, gereken ihtiyaçlara göre revize edilerek çocuklar reklamların olumsuz etkilerinden korunmalıdır (Ertunç, 2011). Bu noktada okul öncesi öğretmenleri ve öğretmen adaylarının bilinçli olmaları ve farkındalık sahibi olmaları sorumluluklarını yerine getirmeleri ile güncel olarak denetimin toplum tarafindan yapılmasını sağlayacaktır.

Mevcut araştırmada öğretmen adayları tarafindan reklam içeriklerinde tahmin edilen çocuk hakları arasında katılım hakkının yer almadığı dikkat çekmektedir. Ancak günümüzde çocukların kendileri ile ilgili karar verme sürecinde daha aktif olmaları doğrultusunda bir yönelimin geliştiği fakat gelenekçi yaklaşımın devam etmekte olduğu ve bunun sonucu olarak çocukların görüşlerinin yeteri kadar dikkate alınmadığı söylenebilir (Akyol, 2011). Correia ve arkadaşları (2020) erken çocukluk eğitimi ortamlarında çocukların katılımı hakkında öğretmenlerin fikirleri araştırdığı çalışmada hem çocukların hem de yetişkinlerin başlattığı faaliyetlerin çocuk katılımını desteklemek için iyi bir uygulama olduğu belirtilirken, özellikle yaşlı ve kurumsal öğretmenlerin çocuk katılımının uygulanmasında bağlamsal kısıtlamaları olduğu vurgulanmıştır. Koran ve Avc1 (2017) okul öncesi öğretmenlerinin sınıf etkinliklerine katılma haklarına ilişkin davranışlarını analiz ettikleri çalışmalarında bazı öğretmenlerin çocuk merkezli ve demokratik davranışları sergiledikleri 
çocukların istek ve görüşlerini dikkate alıp buna göre karar verirken; bazı öğretmenlerin katılım gereksinimleri açısından olumsuz davranışlar sergilediklerini saptamıstır. Çocukların katılım hakkı denince kapsamı iyi bilinmemektedir. Örneğin çocuk haklarına duyarlı medya dendiğinde daha çok çocukların medyadan ve medyada korunması anlaşılmakta, ancak çocukların kendilerini ifade etme, düşüncelerini açıklama ve medyadan gereksinimleri olan bilgiyi edinme hakları üzerinde çok durulmamaktadır. Bu nedenle çocukların ifade ve bilgi edinme haklarını bir sorumluluk olarak tanımlayan yeni ilkelerin de etik olarak dikkate alınması, medyanın çocuklara ilişkin sorumlulukları açısından anımsatıcı ve yol gösterici rolü olduğu unutulmamalıdır (Uzun, 2018). Bu durumda çocuk haklarının gözetildiği düşünülen reklam içeriklerinde ve düşünülen çocuk hakları kategorilerinde katılım hakkının yer almamasını medyanın sorumluluğunu yerine getirmediği şeklinde yorumlanabilir. Yine çocuk haklarının gözetildiğini düşündükleri reklam içeriklerinden beslenme içeriğinde yer verildiği bulgusu Akay, Atalay Oral, Akpınar ve Gül (2016)'ün çalışma sonuçlarının ışı̆̆ında çocuk haklarının tanınması, öğrenilmesi açısından yapılacak reklamlarda beslenme araçlarına yer verilmesi gerektiğini düşündürmektedir.

Reklamlarda olumlu yönde aile-toplumsal cinsiyet, çevre-doğa ve bilim-teknoloji ile ilgili pozitif bir tablo oluşturulabilmekte ya da izleyiciler tüketiciler olarak inşa edilmekte ve ürünlerden alınan zevke vurgu yapılmakta, tüketim kültürü normalleştirilip doğallaştırılabilmektedir (Boztepenin 2018). Dolayısıyla reklamların tüketim toplumu vurgusu yapması araştırma bulgularında yer alan sürdürülebilirlik içeriğiyle ilgili çocuk haklarının gözetilmediği bulgusunu destekler niteliktedir. Ayrıca reklamlarda reklamların çocuk mahremiyetini zedelenmesi, sosyal anlamda çocuğun toplum içinde kendini görmesinde ve ilişkilerini geliştirmesinde yanlış algılamalar ve yönlendirmelerin olması çocuğun yaşamını olumsuz etkileyecektir (Önder Memiş, 2019). Kültürel anlamda, çocuğa bakış, çocuk kavramına yaklaşım değişikliğine olan ihtiyaç reklamlarda çocuk hakları konusuna önem verilmesi bir gereksinimdir.

Araştırmanın bir başka alt amacına yönelik olarak öğretmen adaylarının çocuk haklarının gözetilmediğini düşündükleri internet ve televizyon reklamları farklı kategorilerde incelenmiştir. İnternet ve televizyonda izlenen reklamlardan öğretmen adaylarının çocuk haklarının gözetilmediğini düşündüğü reklamların sınıflandırmasında dijital oyun ve oyuncakların yer alması Alabay ve Yağan Güder'in ( 2014) çalışma sonuçlarıyla desteklenmektedir. Alabay ve Yağan Güder (2014), oyuncak reklamlarının genel olarak renk, sunuluş biçimi, oyuncağın işlevi, oyuncakta yer alan karakterler, reklamda yer alan müzik, reklamı seslendiren kişinin cinsiyeti ve oyuncağı tanımlayan reklam metni gibi alt başlıklarda toplumsal cinsiyet rollerini yeniden ürettiği ve belirgin olarak kalıp yargısal bir bakış açısı ile geleneksel rolleri sunduğuna ayrıca; oyuncak reklamlarında, 
kı çocuklarının ve erkek çocuklarının oyuncaklarının cinsiyetlerine göre ayrılması gerektiği alt mesajlarının da güçlü bir şekilde vurgulandığına değinmişlerdir. Ezmeci ve arkadaşları (2017) da çalışmalarında reklamlarda sıklıkla cinsiyete yönelik ayrımcılık unsurlarının bulunduğunu belirlemişlerdir. Tatlow-Golden ve Garde (2020) ise sağlıksız gıda pazarlamasının zararlı olduğunu ve sağlıksız diyetlere, çocukluk çağı aşırı kilolarına, obeziteye ve kilo alımıyla ilgili hastalıklara katkıda bulunduğunu kesin olarak göstermektedir. Böylesi içeriklerin sadece çocukların sağlık ve gıda haklarını değil; aynı zamanda mahremiyet ve sömürüden uzak, özgür olma haklarını da ihlal ettiği vurgulanmıştır.

Reklamlarla çocuklara aktarılan mesajlar, davranış kalıpları, roller ve değerler arasında; kültürel değerler, tüketim kalıpları, cinsiyet rolleri, alternatif yaşam biçimleri, aile içi ilişkiler ve rol dağılımları yer almaktadır. Bu nedenle reklam etiğine sahip kissiler sorumluluklarını özenle yerine getirmelidir. Ancak reklamı hazırlayanlar bu etik sorumlulukların her zaman hatırlayamamakta ve bazen bu çerçevenin dışına taşmaktadırlar. Bu gibi durumlarda devreye yasal düzenlemeler girmekte ve çocuğun reklamlar ve reklamlarda verilen mesajlar karşısında korunması görevini üstlenmektedir. Türkiye'de reklamlar konusunda düzenleyiciler; Sanayi ve Ticaret Bakanlığ1 Reklam Kurulu, Radyo ve Televizyon Üst Kurulu ile Reklam Öz-Denetim Kurulu'dur. Bunların tamamının farklı görevleri, yetkileri ve işlevleri vardır (Elden ve Ulukök, 2006). Öğretmen adaylarının yasal sorumlu kurul ve kurumların sorumluluklarını görev ve işleyişlerini bilmeleri ve gerekli durumlarda bildirimde bulunmaları gereklidir.

Öğretmen adaylarının mevcut araştırmada reklamlarda gözetilmediğini belirttikleri diğer haklar ise; gelişime uygun olmayan performans kategorisinde yer alan reklamlarla gelişim hakkı, kişisel bakım reklamları kategorisindeki reklamlarla gelissim ve korunma hakk1, beslenme kategorisinde fast food yiyecekler, kola, çikolata, dondurma içerikli reklamlarla yaşama hakkı olarak ifade etmişlerdir. $\mathrm{Bu}$ kategorilerden biri olarak yaşama hakkı dahilinde ele alınan beslenme kategorisine ilişkin yapılan bir araştırmada ebeveynleri daha az fast food tüketen çocuklar arasında fast food TV reklamlarına yüksek düzeyde maruz kalmanın, fast food' u daha sık tüketen bir ebeveyne sahip olmak kadar etkili olduğu belirlenmiştir (Emond 2019). Yani çocuğun düşünceleri üzerinde izlediği reklamın birlikte yaşadığ1 anne ve babasından daha etkili olabildiği söylenebilir.

Televizyon reklamlarının besin seçimi üzerine etkisini inceleyen Günlü ve Derin ( 2012) çalışma sonucunda 9-14 yaş grubu çocukların çoğunlukla reklamlarını beğendikleri ve yiyecek reklamlarından; çikolata, cips, kek ve şekeri, içecek reklamlarından da; kolalı içeceklerin reklamlarının beğendiklerini belirtmiştir. Öğrencilerin büyük kısmının çok satın aldıkları yiyecek 
türlerinin ilk sıralarda çikolata, cips, kek ve şeker ile fastfood; içecek türlerinin ise kolalı içecekler ve hazır meyve suları olduğu saptanmıştır. Yapılan seçimler sağlılı olmamakla birlikte çocukları reklam aracılığıyla sağlıklı yaşam hakkı ellerinden alındığı düşünüldüğünden araştırma bulgusunu destekler niteliktedir. En çok televizyon izlenme oranlarına sahip prime time 20.00-22.59 saat diliminde en yüksek reytingli programlar belirlenerek bu programlar arasında yayınlanan reklam kuşakları içerisinde çocuk öğesini herhangi bir şekilde barındıran reklamlar olduğu saptanmışır (Ezmeci vd., 2017). Bu durum araştırma bulgusu olarak korunma hakkının gözetilmediği görüşünü çocuk hakları açısından desteklemektedir

Niteliği gereği reklam tanıttığı ürün ya da hizmetle ilgili bir takım abartılı ifade ve görüntüler kullanarak ortalama tüketici için bir sorun teşkil etmezken, reklamı izleyen çocuklar açısından bazı olumsuz etkilenme ihtimallerini doğurabilmektedir. Reklamlar, çocuk ve gençlere zihinsel, fiziksel veya ahlaki açılardan zarar verebilecek, sağlık ve güvenlikleri bakımından tehdit niteliğindeki etkilere neden olabilecek ya da teşvik edebilecek ifade, yorum, sunumlara yer vermemelidir (Ertunç 2011). Bu noktada reklamı hazırlayanlara diğer kişilere oranla daha fazla görev düşmektedir (Elden ve Ulukök, 2006). Ertunç (2011) çalışmasında çok bilinen bir içecekle ilgili televizyon reklamlarında ulusal düzeyde idari para cezası ve reklam yayınını durdurma cezası verildiğini belirtmiştir. $\mathrm{Bu}$ durum şirketlere verilen cezaların caydırıcı özellikte olduğunu ve şirketlerin daha olumlu ve çocuk haklarını koruyucu reklamlar yaptıkları sonucuna varılabilir. Demirci (2016) Sütaş, Muratbey, Sek ve Yörükoğlu markalarının işçilerin belli temel haklarının reklamlarda nasıl sunulduğunu incelediği çalışmada reklamlarda işçilerin haklarının görünmez kılındığını ortaya koymuştur. Direk çocuklara yönelik olmayan bu sonuçlar çalışlan reklamların içecekle ilgili reklamlar olduğu düşünülürse öğretmen adaylarının beslenme kategorisinde çocuk haklarına uygun reklamların olmadığ1 görüşünde olduklarını desteklediği söylenebilir.

Mevcut araştırmada öğretmen adaylarının en sevdikleri reklamlar ve bunların çocuk haklarını dikkate alması durumu sorulmuş olup; en sevilen reklamların çokluk sırasına göre yiyecek içecek, kutlama/hediyeler, spor, çevre, kamu spotu, sivil toplum kuruluşları kategorilerinde oldukları belirlenmiştir. Bu reklamları değerlendirmeleri istenildiğinde öğretmen adaylarınca en çok sevilen reklamların çocuk haklarını tamamen ve kısmen dikkate aldığı görülmektedir. Bu durum, öğretmen adayının reklam vasıtası ile çocuklarda ve ailelerde oluşturulacak bilinç üzerinde etkisi olacağını göstermektedir. Yani ebeveyn ve çocukları bilinçlendirme ve uygun olmayan bildirileri yapmaları konusunda öğretmen adaylarının cesur davranacağını düşündürmektedir. 
Öte yandan reklamı yapılan ürün ya da hizmetin yetişkinlere yönelik olması, reklamcıların çocuklara yönelik yasal düzenlemelerle belirlenmiş yükümlülüklerini yerine getirmesi gerekliliğini ortadan kaldırmamaktadır. Çocuklar reklamların hem öznesi hem de nesnesi olarak ürün ya da hizmetlerin satın alınması veya aldırılması noktasında ebeveynlerine ya da aile büyüklerine ihtiyaç duyacağından, reklam mesajlarının çocuklar ve yetişkinler nezdinde kabul görmesi esastır. Reklam mesajlarında iknaya dayandırılan reklam kurguları tercih edilmektedir. Öğretmen adaylarının da en sevdikleri reklamların yiyecek içecek kategorisinde olması yetişkin olarak onların da reklamın cazibesine kapıldıklarını ortaya koymaktadır. Öğretmen adaylarının öğretmen olduklarında da bundan etkilendiği düşünülürse öğrencilerin onları model alacağı düşüncesiyle bu bulgu geleceğe yönelik endişe verici olarak algılanabilir. Buna ilaveten, çocuklara yönelik reklam pazar payının önemli bir bölümünü düşük nitelikli besin ya da gıda grubu reklamları oluşturmaktadır. Ancak belirtilen türdeki ürün reklamlarının yaygınlaşması, çocukların sağlıksız beslenmelerine bağlı gelişebilecek obezite problemi ile toplumları karşı karşıya bırakmaktadır. Bu nedenle, pek çok gelişmiş ve gelişmekte olan ülkede bu problemle ilgili olarak bu türden ürün reklamlarına ilişkin çeşitli kısıtlamalar ve yasal düzenlemeler getirilmektedir. Ülkemiz için ise bu durumun zaman içinde olumlu yönde gelişen bir seyir gösterdiğini söylemek mümkündür (Ertunç, 2011). Ancak bu gelişmenin istenir düzeyde olmadığ1 söylenebilir.

Çocukların medyada özellikle reklamlarda temsil ediliş şekilleri, toplumdaki yetişkinlerin çocukları nereye, nasıl ve hangi amaçla konumlandırdıklarının izlerini taşımaktadır. Öğretmen adayları olarak bu yüzden özellikle en çok sevdikleri reklamların kendileri çocuklara önem verdikleri için çocuklara yönelik içerikte olduğunu düşünmelerine neden olmuş olabilir. Bu nedenle reklamlarda örtük imalar ile kodlanan mesajları anlamak açısından ilk başta bireysel olarak, eleştirel bakış açısını kazanmamız gerekmektedir. Dumlu (2017) söylemlere karşı eleştirel bir bakış açısı kazanmamış bireylerin, olanı olduğu gibi kabul etme, sorgulamama ve kanıksama gibi yanlış bilinç öğeleri ile donatıldığı için, yönlendirilmesi de çok daha kolay bir hale gelebildiğinin altını çizmiştir. Reklamlarda çocuklar aracıllğı ile ailelere verilen mesajların çoğu ebeveynlik duygusuna yönelik olup, çocuğu koruma, mutlu etme isteği, sağlıklı ve doğru beslenmesini sağlama, yaratıcılık ve hayal gücünü destekleme, eğitim/ başarı/ gelecek, çocuğu ile nitelikli vakit geçirme, iyi bir birey olmasını istemedir (Ezmeci vd. 2017). Bu durum öğretmen adaylarının da geleceğin ebeveynleri ve yetişkin bireyleri olarak kendilerini tanıyarak en sevdikleri reklamların içeriğinin onları etkilediği söylenebilir.

Araştırmada incelene son alt amaca göre öğretmen adaylarının reklamlarla çocuk haklarının korunmasının mümkün olup olmadığına ilişkin görüşleri alınmıştır. Buna göre öğretmen adaylarının yarı yarıya farklı görüşlerde olduğu ancak çok az farkla reklamlarla hakların korunabileceğini 
(\%53’ünün) düşündükleri saptanmıştır. Hangi hakkın reklamlar aracığı ile korunabileceğine ilişkin olarak ise çoğunlukla gelişim hakkı, yaşama hakk1 ve korunma hakkının korunabileceği en az ise katılım hakkının korunabileceği ifade edilmiştir. Konuya çocukların gözünden bakan bir çalışma yürüten Meral (2011) 2-6 yaş arasını kapsayan çocukların, televizyon vasıtasıyla edindikleri duyumları 3 yaşına kadar düşünce süzgecinden geçirmeksizin, taklit ettiklerini, çocuğun adeta televizyonun dünyasına girdiğini ve kendini reklamlardaki karakterlerle ya da yaşamla özdeşleştirdiğini belirtmiştir. Bu durum mevcut araştırma sonucuyla birlikte ele alındığında; reklamlarda çocuklara sunulacak olumlu içeriklerle çocukların özdeşim kurması sağlanarak reklamlar aracılığı ile çocuk haklarından gelişim, yaşama ve korunma haklarının korunabileceği söylenebilir. Ancak bu noktada televizyon ve internet kullanımı konusunda çocuğa özdenetim ve otokontrol aşılamanın, medya etiği, medya okuryazarlı̆ğ ve çocuk hakları eğitiminin önemli ve gündem konusu olduğu ortaya çıkmaktadır.

Çocuk hakları bağlamında reklamlar göz önünde bulundurulduğunda, reklam iletilerinden sorumlu tüm muhattaplar birlikte çözüm üretmelidir. Öğretmen adayları da içinde bulundukları öğrencilik dönemi ve ileride öğretmen olduklarında bu muhataplardan önemli kişilerdir. Teknoloji çağı olan bu dönemde öğretmenlerin çocuk hakları konusunda farkındalık sahibi olması çocuk hakları ihlallerinin bildirilmesi ve gerekli önlemlerin alınması ile çocuk haklarının uygun reklam içerikleri ile geliştirilebileceği düşünülmektedir. Ailelerin de bu konuda bilgilendirilmesi sağlanarak çocuk hakları ihlalleri azalarak, takibi sürekli devam edecektir.

Çocuğun yüksek yararının gözetilmesi, kendi görüşünü ifade etme özgürlüğünün yanı sıra genel düşünce-vicdan özgürlüğü, özel yaşamın korunması, bilgiye erişim, eğitim hakkı gibi yaşamsal insan hakları ve özgürlüklerinin teminat altında tutulması medyada gereklidir. Bireylerin gerekse toplumun bir bütün olarak, medya eleştirisi, medya okuryazarlığ1 üzerine bilinç- farkındalık geliştirilmesi gerekse duyarlı sivil toplum kuruluşlarının demokratik kitle örgütleriyle bütünleştirilip, toplumsal duyarlılık kanallarının uyanık tutulması sağlanarak çocuk hakları noktasında, medyada kalıcı bir düzelme gerçekleşebilir (Dural ve Dural, 2015). Öğretmen adaylarının medyanın bu konudaki rolü konusunda gelişim, yaşam ve korunma haklarının reklamlar yoluyla korunabileceğini düşünmeleri katılım hakkını uygulamadan çok daha uzak görmelerinden kaynaklanabilir.

Sonuç olarak araştırmada ele alınan amaç doğrultusunda yapılan incelemelere dair; okul öncesi öğretmen adaylarının çocuk haklarına ilişkin bilgiye sahip oldukları, çocuk haklarının korunduğunu düşündükleri reklamların daha çok şirketler ya da sivil toplum kuruluşları tarafindan üretilen içerikler olduğu ve burada da en çok yaşama, gelişim ve korunma haklarının yer aldığını 
düşünmektedirler. Bununla birlikte genel anlamda reklamlarda korunmadığını düşündükleri çocuk hakları da sırasıyla yaşama, gelişim, korunma ve katılım haklarıdır. Öğretmen adaylarından en sevdikleri reklamı düşünmeleri ve bu reklamda çocuk hakkının korunup korunmadığını değerlendirmelerine göre ise yine sevdikleri reklamların yaşama, gelişim ve korunma haklarını koruduğunu düşündükleri ortaya çıkmıştır. Son olarak reklamlarla çocuk haklarının korunmasının imkanı olup olmadığı sorulduğunda ise mümkün olduğunu ifade ettikleri görülmüştür. Bu sonuçlar ışı̆̆ında çocuk hakları bağlamında mevcut araştırmada şirketlerin reklamlar aracılı̆̆ı ile sorumluluğunu yerine getirdiği düşünülmekle beraber yürürlükte olan mevzuat ile gerekli önlemler alınsa bile denetleme sürecinde sorumluların sadece kurumlar değil, okul öncesi öğretmenler, öğretmen adayları, ebeveynler ve tüm toplum olduğu unutulmamalıdır.

Çocuklar bir davranışın doğru ya da yanlış olduğu konusunda öncelikle ailelerine daha sonra da öğretmenlerine inanmaktadırlar. Bu nedenle geleceğin öğretmeni olan öğretmen adaylarının özellikle reklamların genel yapıları üzerine bilgi sahibi olmaları gereklidir. Bu çerçevede Trakya Üniversitesi öğretmen adayları üzerinde yapılan bu araştırma gibi farklı üniversitelerin okul öncesi ve diğer öğretmenlik branşlarında benzer çalışmalar yapılarak farkındalıklarının arttırılması önerilebilir. Buna ek olarak öğretmen adaylarının bilgi birikimini desteklemek üzere yeni medya, medya okuryazarlığı ve medya etiği konusunda fakültelerinin müfredatlarına Çocuk Hakları ve Gazetecilik Uygulamaları gibi derslerin eklenmesinin önemli olduğu düşünülmektedir. Böylece çocuk hakları konusunda çok daha bilinçli okul öncesi eğitimcileri yetişerek çocuk hakları koruyucusu ve geliştiricisi olacak, ebeveynlere de bu konuda rehber olacaktır.

Reklamın bilgilendirme ve sosyalleşme işlevi göz önüne alındığında çocuk hakları bağlamında reklamlar ile çocuklara ulaşmayı sağlayacak reklamların yapılması önerilebilir. Bunun yanı sıra çocuk haklarının medya aracıllğı ile korunabilmesi ve bilgilendirilmesi konusunda diğer bir taraf olarak medya profesyonellerinin çocuk hakları ve etik konusundaki görüşleri incelenebilir.

\section{KAYNAKÇA}

Akay, A. Ş., Atalay Oral, M., Akpınar, M.G., Gül, M. (2016). Reklamların marka bilinirliği açısından değerlendirilmesi: Meyve suyu ürünleri örneği. Akademik Arasstırmalar ve Çalssmalar Dergisi, 8(15),199-210.

Akman, B. ve Ertürk, H.G. (2011). Okul öncesi ögretmenlerin cocuk baklarna ilişkin bilgi düzeylerinin ve okul öncesi dönemde çocuk haklarmm ögretilmesine ilişkin görüslerinin incelenmesi. 1. Türkiye Çocuk Hakları Kongresi Yetişkin Bildirileri Kitabı, İstanbul: Çocuk Vakfı Yayın No: 90, S.1, 269284. 
Akyol, S.(2011). Cocuk Haklar'na dair sözleşme çerçevesinde çocuğun görüslerime sayg ilkesi (varlğgnm sabibi olan cocuk). 1. Türkiye Çocuk Hakları Kongresi Yetişkin Bildirileri Kitabı, İstanbul: Çocuk Vakf1 Yayınlar1: 90, S.1, 183-188.

Akyol, T. 2020. Anne Babaların Çocukların Katılım Hakkına Yönelik Görüşleri. Gümüş̧ane Üniversitesi Sosyal Bilimler Enstitüsü Elektronik Dergisi, 11; 331-346.

Alabay, E. ve Yağan-Güder, S. (2018). Oyuncak reklamlarının mesajı: bana cinsiyetini söyle, sana oyuncağını söyleyeyim. Akdeniz Üniversitesi Edebiyat Fakültesi İngiliz Dili ve Edebiyatı Bölümü, I. Dil, Kültür ve Edebiyat Çalıştayı. 11 Eylül 2019 tarihinde https://www.academia.edu/18991683/oyuncak_reklamlarının_mesai1_bana_c\%c4\%b0ns $\%$ c4\%b0yet $\%$ c4\%b0n\%c4\%b0_s\%c3\%96yle_sana_oyunca $\%$ c4\% $\% 9$ enn_s\%c3\%96yleyey $\% \mathrm{c} 4 \% \mathrm{~b} 0 \mathrm{~m}_{\text {_ }}$ adresinden erişildi.

Anonim (2019). Generation Y \& Technology. 26 Haziran 2019 tarihinde http://www.generationy.com/about-generation-y-in-the-workforce/generation-y-andtechnology/ adresinden erişildi.

Aydınlık, A. (2017). Çocuk Haklarının Gelişiminde Okul Öncesi Eğitimin Yeri Ve Önemi: “Ankara Örneği”. Başkent Unvversity Journal Of Education, 6(2); 1-98.

Banko, Ç. (2017). Okul öncesi ögretmenlerinin çocuk haklarna ilişkin tutum, davranış ve görüşlerinin incelenmesi. Hacettepe Üniversitesi İlköğretim Ana Bilim Dalı Okul Öncesi Eğitimi Bilim Dalı, Yüksek Lisans Tezi.

Bilir Seyhan, G. ve Arslan Cansever, B. (2017). Öğretmen Adaylarının “Çocuk Hakları”na İlişkin Algılarının Materyal Tasarımları Ve Görüşleri Çerçevesinde İncelenmesi. Mehmet Akif Ersoy Üniversitesi Eğitim Fakültesi Dergisi, ISSN:1302-8944, 41; 98-119.

Boztepe, V. (2018). Televizyon reklamlarının toplumsal işlevleri üzerine göstergebilimsel bir çözümleme: Toyota Hibrit örneği. Anadolu Üniversitesi İletişim Bilimleri Fakültesi Uluslararası Hakemli Dergisi, 26(1), 26-47.

Christensen, L. B., Johnson, R. B. \& Turner, L. A. (2015). Nitel ve karma araştırma yöntemleri. Çev. M. Sever. Çev Ed. A. Aypay. Araştırma yöntemleri desen ve analiz içinde s.400433. Ankara: Anı.

Creswell, J. W. (2017). Temel ve gelişmiş karma yöntem desenleri. Çev. İ. H. Acar. Çev. Ed. M. Sözbilir. Karma yöntem araştırmalarına giriş içinde s.35-52. Ankara: Pegem Akademi.

Creswell, J. W. \& Plano-Clark, V. L. (2015). Karma yöntem desen seçimi. Çev. A. Delice. Çev Ed. Y. Dede ve S. B. Demir. Karma yöntem araştırmaları tasarımı ve yürütülmesi içinde s.61- 116. Ankara: An1.

Correia,N., Carvalho,H., Durães,J. and Aguiar, C. (2020). Teachers' ideas about children's participation within Portuguese early childhood education settings. Children and Youth Services Review, 111; 104845. https://doi.org/10.1016/j.childyouth.2020.104845

Covell, K., Howe, R. B. (1999). The impact of children's rights education: A Canadian study. The International Journal of Children's Rights, 7: 171-183. 
Cudjoe, E., Abdullah, A. and Manful, E. (2021). Parents' Perceptions on the Outcomes of Children's Participation in Child Protection Meetings in Ghana. Journal of Child and Family Studies (2021) 30:1071-1081 https://doi.org/10.1007/s10826-021-01918-2

Değirmenci, T. (2011). Öğretmen adaylarının çocuk haklarına ilişkin tutumlarının incelenmesi. XX. Eğitim Bilimleri Kurultay1, Burdur, Mehmet Akif Ersoy Üniversitesi, 09 Eylül 2019 tarihinde https://www.pegem.net/Akademi/kongrebildiri_detay.aspx?id=125279 adresinden erişildi.

Demirci K. (2016). Reklamlarda emeğin görünmez kılınması: Süt ürünleri reklamları üzerinden bir analiz. Galatasaray Üniversitesi İletişim Dergisi, 164-185.

Dumlu A. (2017). Reklamalarda çocuğun kullanımına yönelik eleştirel söylem analizi: Omo, Ülker, Johnson's Baby ve Turkcell reklamları örneklemi. Innovation and Global Issues in Social Sciences Congress Book, Patara: Congress Publications, 593-608.

Dural, A.B. ve Dural , Ş. 2015. Reklam iletileri çerçevesinde çocuk güvenliği çocuk hakları ve medya etiği. Elektronik Sosyal Bilimler Dergisi. 14(53), 186-197.

Elden, M. ve Ulukök, Ö. (2006). Çocuklara yönelik reklamlarda denetim ve etik. Küresel İletişim Dergisi, 2: 1-21.

Emond, J.A., Longacre, M.R., Drake, K. M., Titus ,L.J., Hendricks ,K., MacKenzie ,T., Harris ,J.L., J Carroll , J.E., Cleveland , L.P., Gaynor , K. and Dalton, M.A. 2019). Appetite, Volume 140; 134-141.

Ergün, B. ve İpek, M.(2020). Erken Çocukluk Döneminde Temel Hak ve Özgürlüklerin Gerçekleştirilmesinde Ebeveyn Tutumlarının İncelenmesi. Aydm İnsan ve Toplum Dergisi, 2; 159-180.

Ertunç, F. 2011. Çocuk dünyasında reklamın rolü: Televizyon reklamlarında çocuklara yönelik düzenlemeler. Radyo ve Televizyon Üst Kurulu Uzmanlık Tezi, Ankara.

Ezmeci, F., Çoban Söylemez, E. T., Esra Akgül, E. ve Akman,B. (2017). Çocukların yer aldığ1 reklamların çocuklara ve yetişkinlere verilen mesajlar, roller ve cinsiyete yönelik ayrımcıllk unsurları açısından incelenmesi. Galatasaray Üniversitesi İletişim Dergisi, 247-247.

Faiz, M.ve Kamer, S.T. (2017).Preservice Teachers' Opinions Concerning Children's Rights. Journal of Education and Learning, 6(3);118-128.

Gunathilaka, P. (2018). Awareness of Preschool Teachers in Sri Lanka on Child Rights. ProceedingsThe International Research Conference In Humanties And Socıal Sciences, University of Peradeniya, 139, Sri Lanka.

Günlü, Z. ve Derin, D.Ö. (2012).Televizyon reklamlarının okul çağı çocuklarının besin seçimi üzerine etkilerinin bir incelemesi. Selçuk Üniversitesi İletişim Fakültesi Dergisi.7(3), 62-77.

Hareket, E. (2019). Temel Eğitim Bölümü Öğrencilerinin Çocuk Haklarına Yönelik Bilişsel Alg1ları. Baskkent Unversity Journal Of Education, 6(2); 167-180.

Kapferer, J.N. (1991). Çocuk ve Reklam. Ş. Önder( Çev), İstanbul: Afa Yayınları. 
Karaman Kepenekçi, Y.(2006). A Study of university students' attitudes towards children's rights in Turkey. The International Journal of Children's Rights, 14: 307-319.

Kardeş, S., Banko, C.., Eren, S. ve Antakyalığlu, Ş. (2017). Okul öncesi öğretmen adaylarının çocuk haklarına ilişkin görüşleri. Akademik Sosyal Araștırmalar Dergisi, 5(54), 469-481.

Kaya, Ö. S. (2011) . Ögrretmen adaylarmm çocuk haklarna ilişkin görüsleri. (Yayımlanmamış Yüksek Lisans Tezi). Afyon Kocatepe Üniversitesi, Afyonkarahisar.

Kent Kükürtçü, S. (2011). 5-6 yas çocuklarn aile ve ögretmenlerinin kullandıklar disiplin yöntemlerinin çocuk hakelar ile ilişkisinin incelenmesi. (YayımlanmamışYüksek Lisans Tezi). Hacettepe Üniversitesi, Ankara.

Kent Kükürtçü, S. (2019). Çocuk haklarn ve demokrasi eğitiminin çocuklarn demokratik davranıslarna etkisi. (Yayımlanmamış Doktora Tezi). Hacettepe Üniversitesi, Ankara.

Kesayak. Y. ve Karatekin; K.(2020). Ebeveynlerin Ailede Çocuk Haklarını Uygulama Düzeylerinin İncelenmesi. Türkiye Bilimsel Arasttrmalar Dergisi TÜB AD, 5(2);211-234.

Kop, Y. ve Tuncel, G. (2010). Sosyal bilgiler öğretmenlerinin çocuk haklarını algılaması. Eğitimde Kuram ve Uygulama, Journal of Theory and Practice in Education, 6(1),106-124.

Kor, K. (2013). Okulöncesi öğretmenlerinin cocuk baklar konusunda görüslerinin belirlenmesi. Yayımlanmamış Yüksek Lisans Tezi). Çanakkale Onsekiz Mart Üniversitesi Eğitim Bilimleri Enstitüsü, Çanakkale.

Koran, N. (2012). Okul öncesi ögretmenlerinin cocuklarn katılım hakker konusundaki uygulamalarnmn ögretmen adayn gözlemlerine göre incelenmesi. Yüksek lisans tezi, Girne Amerikan Üniversitesi, Girne. 10 Eylül 2019 tarihinde https://www.academia.edu/ adresinden erişildi.

Koran, N ve Avc1, N.2017). Perceptions of Preservice Pre-school Teachers Regarding Children's Right to Participate in Classroom Activities Kuram Ve Uygulamada Ë̈itim Bilimleri Educatıonal Scrences: Theory \& Practuce, 17(3);1035-159.

Kozikoğlu, İ. (2017). Okul Öncesi Öğretmenlerinin Çocuk Hakları ve Çocuk Katılım Hakkına İlişkin Görüşlerinin İncelenmesi. Erken Çocukluk Çalsşmalarn Dergisi, 3(2); 380-405.

Lawal, T.O. and Ajayi, H. O.(2020). Parents - children awareness and knowledge of the Child Rights Act and its effect on the children in Nigeria, Technical University Of Varna Annual Journal, 4(1);1-11, https://doi.org/10.29114/ajtuv.vol4.iss1.127.

Leblebici, H. ve Çeliköz, N. (2017). Öğretmen adaylarının çocuk haklarına yönelik tutumları. International Journal of Social Sciences and Education Research, 3(1), 307-318.

Meral, Pinar Seden (2011). Reklam ve Çocuk, Çocuk Haklar ve Medya El Kitabı, İstanbul : Çocuk Vakfi Yayın.

Miles, M, B., ve Huberman, A. M. (1994). Qualitative data analysis: An expanded Sourcebook. 2nd edition. CA: Thousand Oaks, Sage.

Neslitürk, S. ve Ersoy, A. F. (2007). Okulöncesi öğretmen adaylarının çocuk haklarının öğretimine ilisskin görüşleri. Eğitimde Kuram ve Uygulama, Journal of Theory and Practice in Education, 3(2), 245-257. 
Oktay, A. ve Kumbaracıoğlu, N. (2011).Öğretmenlerin ve ögrencilerin çocuk haklarna bakışınn değerlendirilmesi. 1. Türkiye Çocuk Hakları Kongresi Yetişkin Bildirileri Kitabı, İstanbul: Çocuk Vakfi Yayın No: 90, S.1, 365-379.

Olsson, A. (2020). Children's Rights in Swedish Teacher Education (İsveç Öğretmen Eğitiminde Çocuk Hakları). Human Rights Education Review (İnsan Hakları Eğitimine Genel Bakış), 3(2); 49-67.

Önder, A. ve Balaban-Dağal, A. (2007). Televizyon ve okul öncesi dönem çocuğu. İçinde A. Oktay ve Ö. Polat Unutkan (Ed). Okul Öncesi Ë̆itimde Güncel Konular içinde (s. 247-264). İstanbul: Morpa.

Önder Memiş, H.B. (2019). Televizyon reklamlarında çocuk mahremiyetinin ihlali. Gümüşhane Üniversitesi İletisim Fakültesi Elektronik. Dergisi, 7(1), 456-481.

Özdemir Uluç, F.(2008). İlköğretim programlarnda çocuk hakelar (Yayımlanmamış Doktora Tezi). Ankara Üniversitesi, Ankara.

Özen,O. (1995). Televisyon Reklamlarmda Çocuk Kullanımmm Yasal ve Ablaki Yönleri (Yayımlanmamış Yüksek Lisans Tezi). İstanbul Üniversitesi, İstanbul.

Özkan, K. (2013). Okul öncesi ögrretmenlerinin cocuk baklar konusundaki görüslerinin belirlenmesi (Yayınlanmamış Yüksek Lisans Tezi). Çanakkale Onsekiz Mart Üniversitesi, Çanakkale.

Öztürk, A . (2019). Development of Children's Rights Education Curriculum for Preservice Preschool Teachers . Journal of Theoretical Educational Science , 12 (4) , 1257-1283 . DOI: 10.30831/akukeg.471086.

Pilatin, G. Ve Ahmetoğlu, E.2020). Okul Öncesi Öğretmen Adaylarının Çocuk Haklarına İlişkin Tutumlarının İncelenmesi. Ondokuz Mayıs Üniversitesi Ë̆itim Fakültesi Dergisi, 39(3);117-136.

Sadıkoğlu, İ. Ve Topsakal C. (2017). Okul öncesi eğitimde çocuk hakları eğitimi çalışmalarına genel bir bakış. Recep Tayyip Erdoğan Üniversitesi Sosyal Bilimler Dergisi, 6: 219-244.

Senemoğlu, N. (2018). Gelişim, Öğrenme ve Öğretim. 26. Baskı. Ankara: Anı Yayıncılık.

Solmaz, B. Ve Yılmaz, R.A. (2012).Medya Okuryazarlığı araştırması ve Selçuk Üniversitesinde bir Uygulama. Selçuk İletişim Dergisi, 7(3);55-61.

Sop, A ve Topçu Bilir, Z. (2021). Üniversite Öğrencilerinin Çocuk Katılım Hakkı Farkındalıklarının İncelenmesi. Disiplinlerarası Çocuk Hakları Araştırması Dergisi, 1(1); 26-45.

Tatlow-Golden, M. and Garde, A. 2020). Digital food marketing to children: Exploitation, surveillance and rights violations. Global Food Security, 27;1-8.

Tokgöz, O. (1982). Televizyon reklamlarının anne-çocuk ikilisine etkileri. Ankara Üniversitesi Siyasal Bilgiler Fakültesi Yaymlar, No: 501.

Tozduman Yaralı, K. ve Güngör Aytar, A. (2017). Okul öncesi sinıflarında çocuğun katıllım hakkının çocukların ve öğretmenlerin görüşlerine göre incelenmesi. Bartın Üniversitesi Eğitim Fakültesi Dergisi, 6 (1), 29-47. 
Uysal Bayrak, H., Gök, H.N., Yörük, E. ve Kaya, E. (2020). Okul Öncesi Dönemindeki Çocukların Gözünden Çocuk Hakları, Uluslararası Erken Çocukluk. Eğitimi Calışmalan Dergisi, 4 ( 2); 6373.

Uzun R. (2018). Çocukların Medyadan ve Medyada Korunması: Çocuklara Yönelik Etik Davranış Kurallarının İncelenmesi. Üsküdar Üniversitesi İletișim Fakültesi Akademik Dergisi Etkileșim, (1), 43-30.

Verdoodt, V. (2019). The Role of Children's Rights in Regulating Digital Advertising. The International Journal of Children's Rights, 27(3); 455-481. https://doi.org/10.1163/15718182$\underline{02703002}$

Washington, F. (2010). 5-6 yaş grubu çocuklarına uygulanan aile katılımlı çocuk hakları eğitimi programının etkililiğinin incelenmesi (Yayımlanmamış Yüksek Lisans Tezi). Marmara Üniversitesi Eğitim Bilimleri Enstitüsü, İstanbul.

Yaman, F. (2009). Reklamcilık sektöründe reklam etiği algilamasının değerlendirilmesi(Yayımlanmamış Doktora Tezi). Afyon Kocatepe Üniversitesi Sosyal Bilimler Enstitüsü, Afyonkarahisar.

Yaşar Ekici, F. (2014). Öğretmen adaylarının çocuk haklarına yönelik tutumlarının bazı değişkenlere göre incelenmesi. Akademike Sosyal Araștırmalar Dergisi, 2(8), 66-77.

Yeşil, Y. ve Fidan, F. (2017). Türkiye'de y kuşağının e-iletişim kullanımı: üniversite öğrencileri üzerinde bir araștırma. Balkan and Near Eastern Journal of Social Sciences, Balkan ve Yakem Doğu Sosyal Bilimler Dergisi, 3(1), 100-109.

Yıldız, A. 2017. Okul Öncesi Dönem Çocuk Kitaplarında Çocuk Hakları. Uluslararası Ĕ̈itim Bilimleri Dergisi, 4 (13); 88-99.

Yılmazsoy, B. ve Kahraman, M. (2017). Üniversite öğrencilerinin sosyal medya bağımlılı̆̆ ile sosyal medyayı eğitsel amaçlı kullanımları arasındaki ilişkinin incelenmesi: facebook örneği. Journal of Instructional Technologies \& Teacher Education, 6 (1), 9-20. 